\title{
The Eurasian Heartland: Overview of a Link between Worlds
}

Geography has powerfully shaped Central Asian foodways, rendering some pursuits more successful than others. Dry, mountainous, and ranging from very hot to very cold, the region is stressful for farmers. Food production always depends on extremely careful management of landscapes. Thus, some introduction to the Central Asian environment begins our work.

The Eurasian heartland is built on a vast scale. The region stretches from north of 55 degrees north latitude at the north tips of Kazakhstan and Mongolia, to just south of 30 degrees in southern Afghanistan. The classic centers of Bukhara, Samarkand, and Tashkent lie near the 4oth parallel. The region lies quite far north, though with a small subtropical fraction. The span is that between southern Canada and southern Texas in North America.

Dry steppes and deserts seem endless until they suddenly come up against mountain walls several miles high. Lakes big enough to be called seas appear from nearly rainless dunes and salt flats. Huge rivers create fertile strips of oasis land bordered by lifeless plains. Travelers by plane, bored with watching the endless flat brown surface of the Kazakhstan steppe far below, are startled when the Tianshan 天山 peaks suddenly appear, so high that they seem to threaten an imminent crash.

The heartland is bordered by a vaguely-defined East Asia, and an even more vaguely-defined western Asia, with extensions south towards the Himalayas and the Tibetan Plateau, and north into Siberia. It contains the second lowest land elevation in the world - the Turpan (Turfan) Depression, sinking to 154 $\mathrm{m}(5 \circ 5$ feet) below sea level. The Caspian steppes are also below sea level in portions near the Caspian Sea. Conversely, mountains soar to world-shadowing heights. The Tianshan rise to $7439 \mathrm{~m}(24,406 \mathrm{ft})$ at the center of the heartland. South of them is the vast Pamir Knot, a complex of ranges reaching 7495 $\mathrm{m}(24,59 \mathrm{oft})$. At the south edge rise the Karakoram Mountains, including the second highest peak in the world, $\mathrm{K} 2$, at $8611 \mathrm{~m}(28,251 \mathrm{ft})$. The vast Altai range, rising to $4500 \mathrm{~m}$ (about 15 ,000 feet), slashes across the region, from southern Siberia into southern Mongolia. These ranges are part of a single vast rugged 


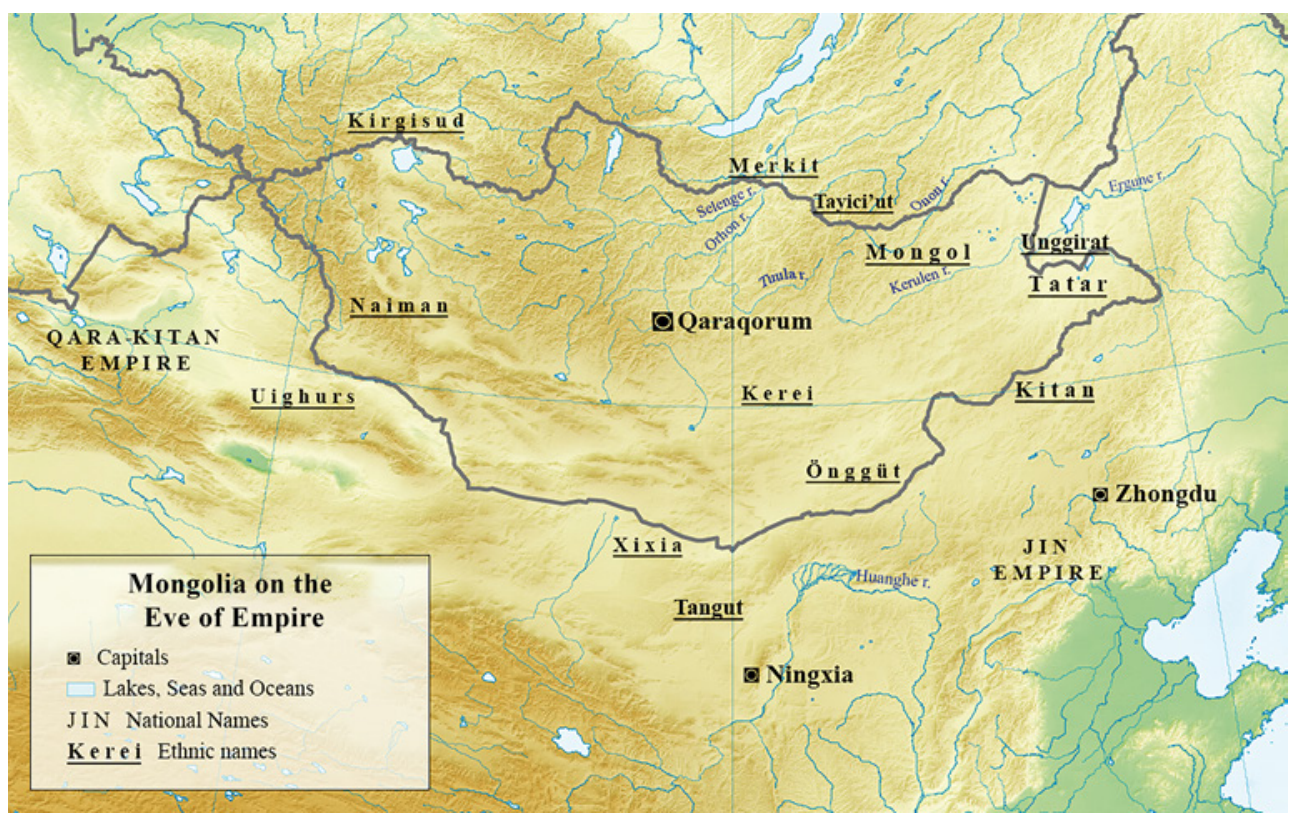

MAP 1 Mongolia on the eve of Empire

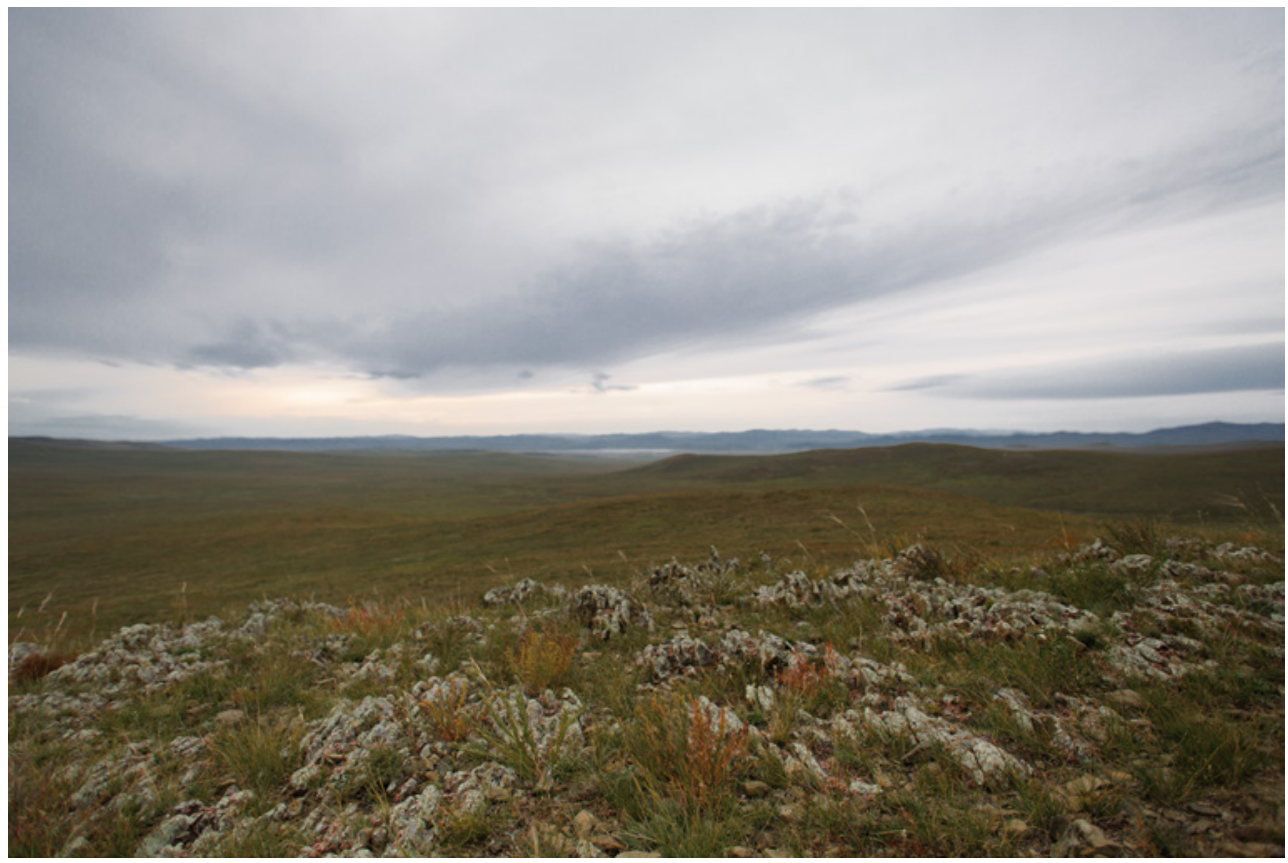

Pното 1 Mongolian steppe 
upland that cuts the Eurasian heartland in two. Modern boundaries, notably those between China and the states of the former USSR, follow this divide.

Other major mountain chains subdivide the region. A bit east of Central Asia, the Xing'an 興安 range stretches through Inner Mongolia, and north to the Amur River. The long, narrow mountain chains of Xinjiang divide that province into several basins, the major ones being Dzungaria in the north and the Tarim Basin in the south. The Altai and Pamirs connect the Tianshan with the Karakoram, creating a vast mountain wall that divides Central Asia in two. Traditionally the western part has looked to Iran; the eastern to China. The current political and linguistic boundaries reflect this divide, as do to some extent, food regions.

Sub-ranges stretch west and have great cultural as well as geographical importance. The Hindukush ("Hindu killer") range cuts Afghanistan in half, separating the Turkic and Tajik north from the predominantly Afghan-Pathan south. The latter is also separated from an ethnically diverse Pakistan by still more ranges. The Kopet Dagh separates Iran from Turkic Turkmenistan.

Thus, much of the region is exceedingly high, useless for human purposes other than rough grazing. Communication usually involved going over high and difficult passes, or through salty and very dry deserts with only occasional oases; this formerly inhibited long-distance trade. Lacking coca leaf- the one genuinely effective folk remedy for altitude sickness - traditional people fell back on long-shot measures. Benedict Goes, a monk traveling in high Asia in the 17th century, reported use there of "garlic, leeks, and dried apples, and the horses' gums were rubbed with garlic."1 How well this worked is unclear.

The mountains bring down orographic rain and are drained by great rivers. The most sizable, and one of the most historically important, is the Volga. It flows into - and largely creates - the Caspian Sea, a vast lake with no outlet. The Ural and Kura (Mtskvari) Rivers are smaller feeders of the Caspian. These rivers are associated more with European than Central Asian history, although the Volga and Ural River zones have strong connections to the Eurasian heartland. During the Mongol period, some of the largest trading communities involved in long-distance trade were focused on the Volga, where many new cities, many of them specially created by the Mongols, were found. ${ }^{2}$

Farther east, the Amu Darya (anciently Oxus) and Syr Darya (Jaxartes) rivers drain the high Pamirs and feed the Aral Sea, now almost dry. Of the older fabled cities of Central Asia, Samarqand and Bukhara are in the Amu Darya drainage, Farghana and Tashkent in the Syr Darya basin. Well east of these, the

Yule (1915), Cathay and the Way Thither, p. 217.

2 Federov-Davydov (2001), The Silk Road and the Cities of the Golden Horde. 


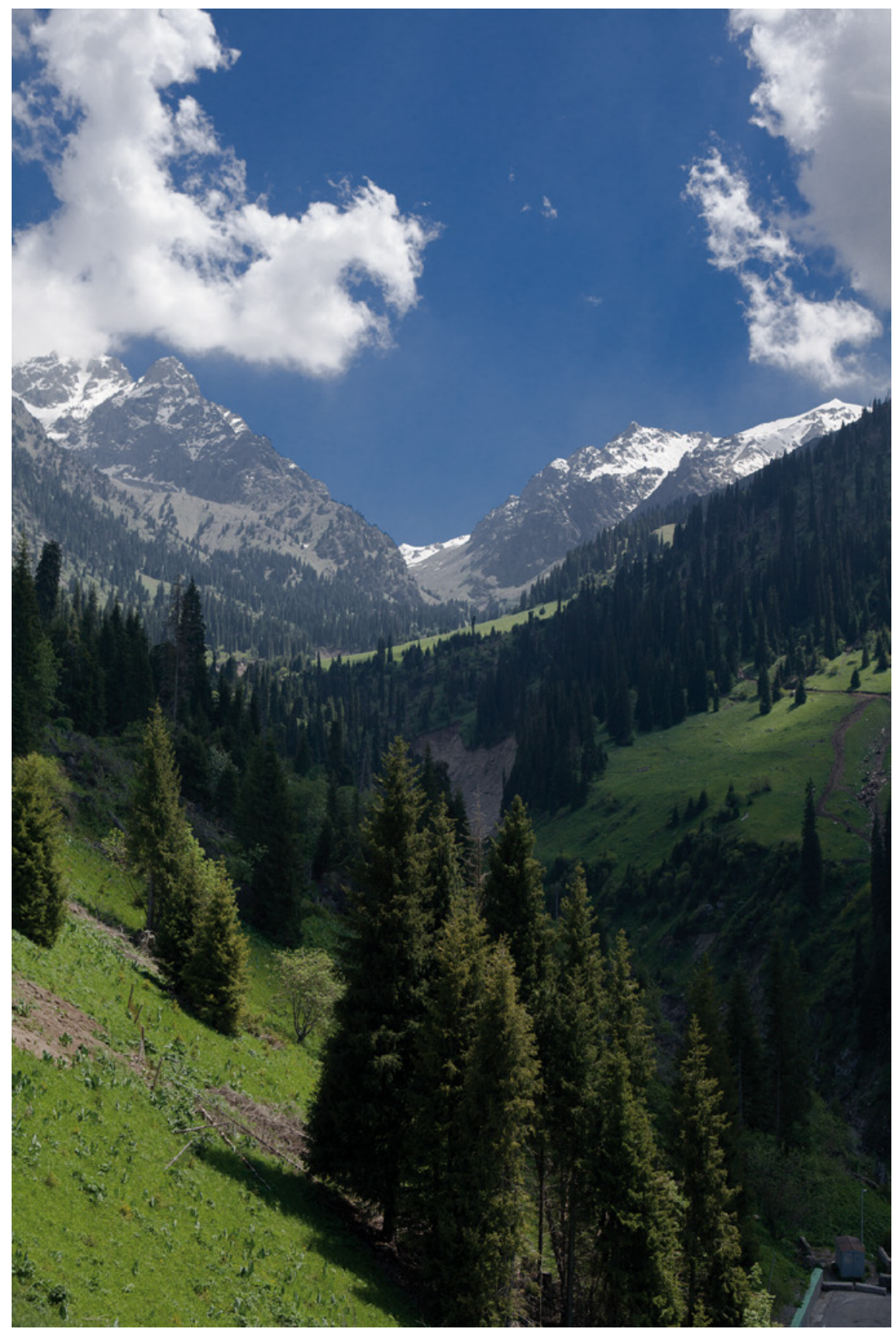

Рното 2 The mountains of Kazakhstan 


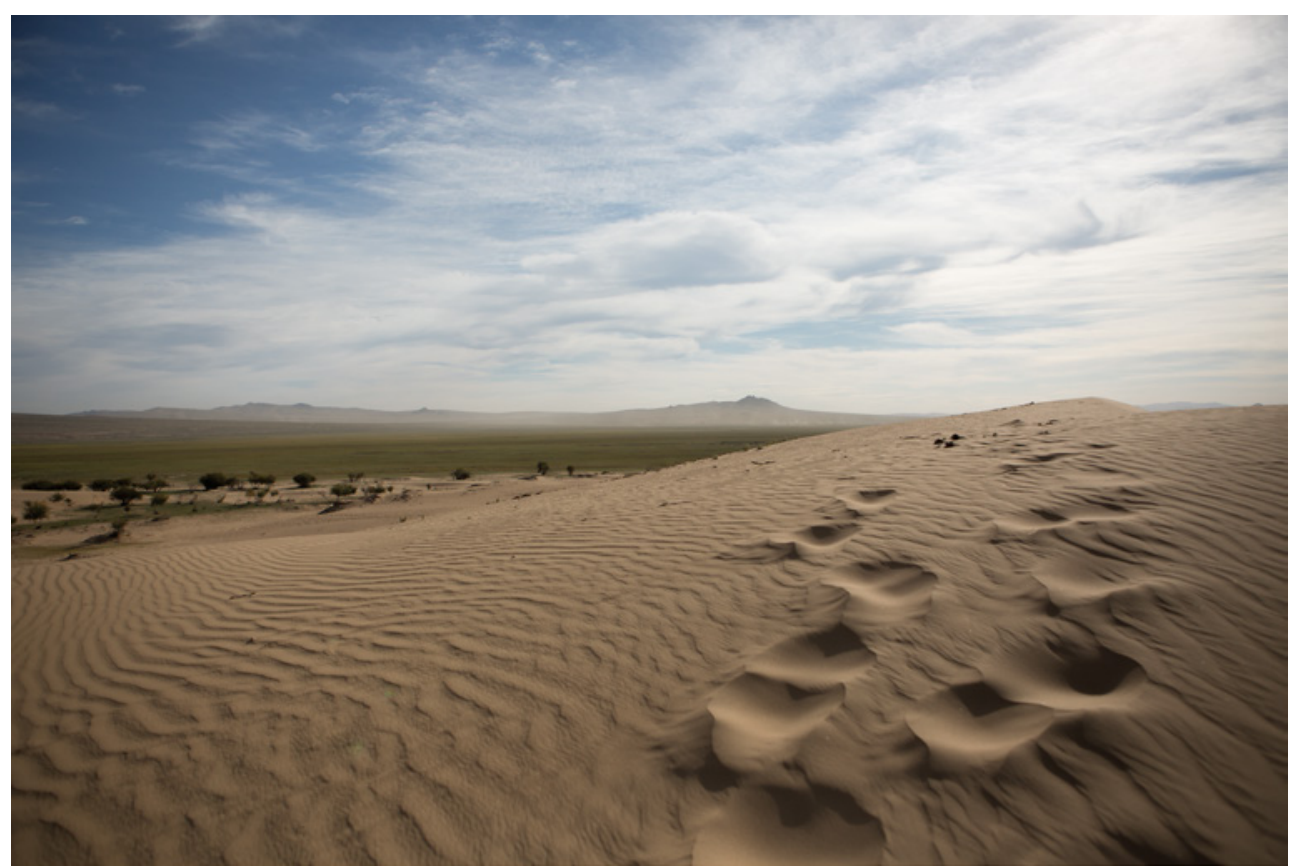

рното 3 Sand desert in Mongolia

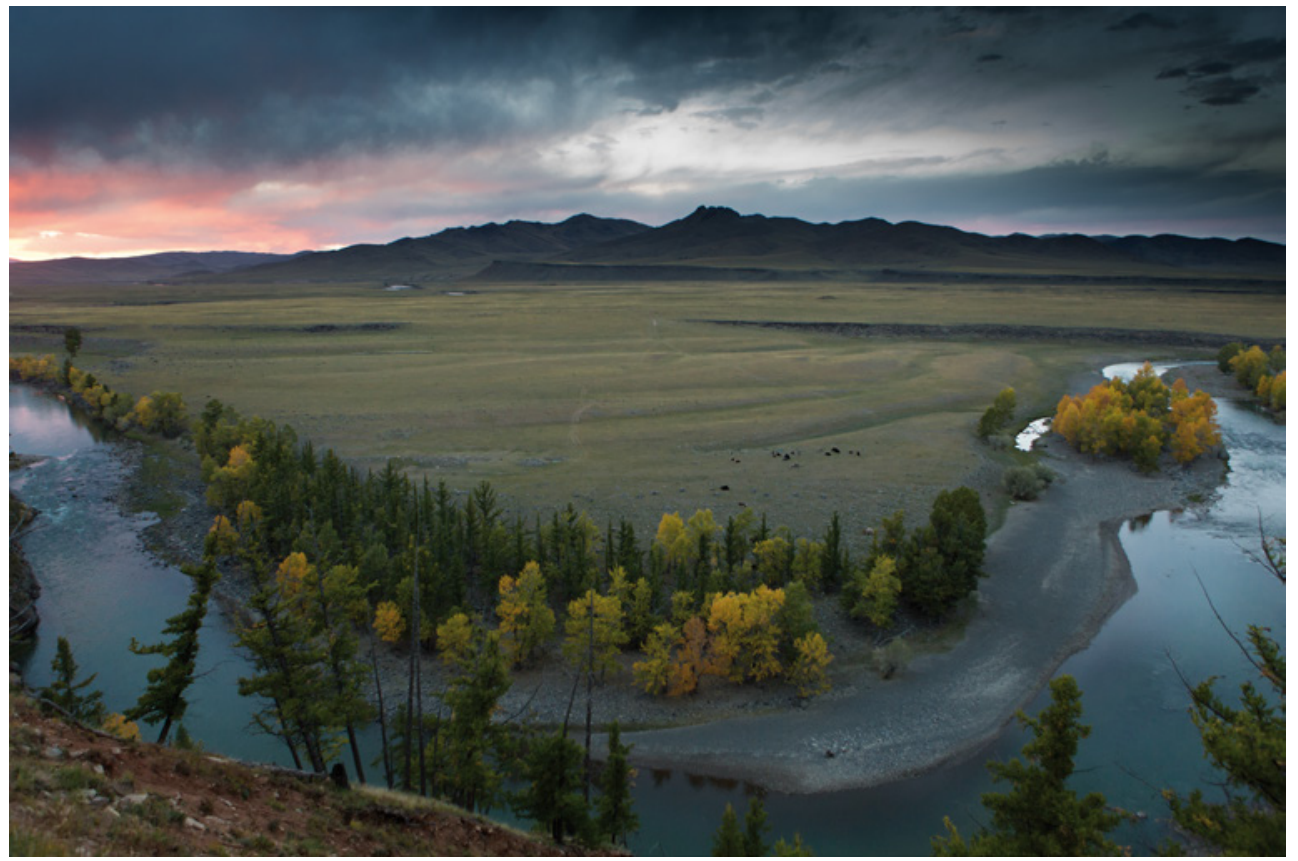

рното 4 The Orkhon 
Tarim River waters much of Xinjiang, including the ancient city of Kashgar. The river creates fertile farmland, but it dies out in the vast sand wastes of the Tarim Basin. It no longer reaches Lop Nor, the famous "wandering lake,"3 which would change location or dry up entirely, depending on the flow of the Tarim. Other smaller rivers create local oases. Unfortunately, most of the drainage from the northerly mountains flows north towards the Arctic Ocean. It is lost to the Eurasian heartland. The northern Altai, for instance, give birth to two of the greatest rivers in the world, the Irtysh and Yenisei, but the Central Asian Altai sees not a drop of their water. (A tiny part of the Irtysh drainage is now in Kazakhstan, in an area with little historical connection to lands southward.) Arctic-flowing rivers also drain northern Mongolia with little historical importance there.

The pervasive problem of the region is lack of rain. Being at the center of a vast continent, and surrounded by mountains, the Eurasian heartland has little chance of being well-watered. The only areas with rainfall adequate to grow much vegetation are the mid-levels of the mountains, and even there, actual forests are rare. Overall, rainfall diminishes from north to south. The steppes of northern Kazakhstan are now dry-farmed; the southern half of the country, and most of the rest of a wider area beyond the mountains, is desert, with farming possible only in irrigated river and lake valleys.

Rain comes largely with the winter and spring westerly winds in the western part of the region. Vast low-hanging storm fronts move slowly through, bringing slight rain to the lowlands, snow to the mountains. Cooler cycles of years produce more rain, because the North Atlantic Oscillation shifts the storm belt southward.

The eastern parts of the Eurasian heartland get their rain largely from the monsoon that brings water across China from the South China Sea. The summer monsoon reaches far north. Also, northerly storms sometimes sweep down from Siberia. In this case, cooler years bring drought, not more rain; they weaken the monsoon and drive south the Intertropical Convergence Zone that lies near the origin of it. Western Xinjiang is the zone of meeting of winter-wet west and summer-wet east, and can have confusing patterns depending on local mountain geography.

Climate change brought several major inflection points to the region. After the Ice Age glaciations, it warmed rapidly, with a long and very warm period starting around 8000 вСE. This came to a rather sudden stop between 2400 and $2000 \mathrm{BCE}$, and colder temperatures supervened, meaning very dry times in the east, and unevenly moister ones to the west. The Han Dynasty coincided

3 Sven Hedin (2010 [1920]), The Wandering Lake. 
with better times from $200 \mathrm{BCE}$ to $200 \mathrm{CE}$; the climate change at $200 \mathrm{CE}$ may have hastened its fall. A very cold period, devastatingly dry in the east, followed volcanic eruptions that darkened the skies in 536-538; cold lasted until around $65^{\circ}$, followed by rapid warming. Then after goo the Medieval Warm Period (or Medieval Climatic Anomaly) gathered force, peaking in the 1200 . After 1300 it gave way rapidly to the Litte Ice Age, which savagely depressed temperatures until around 180o. After that, warming reappeared, accelerated since at least 1850 by human release of greenhouse gases. The effects of all this on history will appear below.

In all cases, it is the mountains that bring down the precipitation. They wring the clouds dry, leaving almost nothing for lands to the leeward. The Turpan and Tarim Basins, surrounded by high ranges on all sides, have almost no rain. Agriculture, and in many cases life itself, depend on the rivers and streams flowing down from the relatively well-watered high country. In the highest places, glaciers and snowfields retain moisture, releasing it when it is most needed, in the heat of summer. Unfortunately, some of these may not store water much longer. Local environmental conditions are changing, in part due to human action.

The vegetation of the Eurasian heartland, both the native and the cultivated, is diverse and well suited to the area. Among the various natural vegetation zones, the Siberian taiga, a beautiful forest, primarily of pine and larch, extends south into northern and Inner Mongolia, and into northeast Kazakhstan. Some of the taiga forests are greatly important in early sources such as the 13th century Secret History of the Mongols, since they were then large enough for ancestral figures such as Chinggis-qan to hide in, when fleeing from his many enemies.

By contrast, most of the mountains of the Central Eurasian heartland are dry and rocky, covered largely with short grass and mountain flowers. There are local belts of forest, including pine, fir, and various hardwoods including birch and hornbeam; these belts get very lush in the ranges of east Kazakhstan and northeast Uzbekistan.

Good pastures, the type of terrain that most quickly comes to mind when thinking of the Eurasian heartland and its stock-raisers, exist only along streams and in valleys where water has seeped into the ground or drained into marshes and lakes. Otherwise, the region is desert or desert-grassland with scattered tufts of grass and small herbs. True grassland, with a fairly continuous cover 
of good grasses, exists, or existed, in northern Kazakhstan, northern and especially northeast Mongolia, Inner Mongolia, and in a few mountain valleys. It has now been replaced by cultivation in most areas outside Mongolia. Many grasslands have been seriously overgrazed in recent years, especially in Inner Mongolia. The grass and herb steppes of northern and central Kazakhstan can bear a standing crop of 48 tons of vegetation per hectare, while the edge of the forest-steppe produces 28 and the desert steppe only $9 .{ }^{4}$ Perennial grasslands store carbon, fixed by a glycoprotein substance called glomalin that is secreted by symbiotic root fungi. Grasslands comparable to northern Kazakhstan's can fix .3 to 1.7 metric tons per acre per year, ${ }^{5}$ producing the famous chernozem soils-black, extremely fertile, dryland soils. The only richer soils in Central Asia are the alluvial soils of the river valleys.

Like other grasslands, the steppes, when not cultivated or overgrazed, accumulate biomass; although they do not grow lushly like tropical forests, they do not decay so fast either. ${ }^{6}$ Dead grass builds up. Especially important is the fact that much, or most of the accumulated biomass is underground, in the form of roots and rhizomes (many of which are important sources of food for livestock and humans). Here it is protected from erosion. Hence the buildup of the famous black soils of moister grasslands: the chernozems of Russia, the prairie soils of the American Midwest, and the darker parts of the loess of Inner Mongolia and northwest China. Even desert grasslands have good, if sometimes fragile, soils. Unfortunately, when stripped of grass cover, all these soils erode rapidly.

Romantic photographs have accustomed Westerners to seeing the steppes as waves of lush green grass. This is true only in a few blessed areas. Most of the steppe and desert land is as brown, dry, and desolate as the bleakest parts of the American Great Basin, or the Sahara fringes of Morocco and Algeria. To survive, nomads range over huge areas. Moving seasonally, they lead their hardy breeds of stock from thin winter pasture in the plains to lusher but hard-toreach mountain meadows. They also move to and along seasonal watercourses in the lowlands. These are the two basic patterns of movement, the first being known in Turkic languages as yailaq kishlaq, "summer and winter pastures."

4 Kuzmina (2008), The Prehistory of the Silk Road, 11.

5 Tallgrass Ontario (2014),"Tallgrass Prairie and Carbon Sequestration." <https://www.tall grassontario.org/carbon_sesquestration.html?fbclid=IwAR3bWOGegsGcdrmGeWRSE2vsDE jpFIdyQgiZ_h7zcowscoDKI_2vF3IP5WE>.

6 Carvalhais, Forkel, Khomi, et al., "Global Covariation of Carbon Turnover Times with Climate in Terrestrial Ecosystems," Nature 514 (2014), 213-217. 
Thin dry steppe grasses prevail in the next belt south, slowly giving way to desert, but the desert is not homogeneous. It ranges from rocky montane country with a highly diverse cover of small perennials and annuals to vast lifeless fields of dunes and salt flats. Most of it is level plain, often covered with pebbles; this is "desert pavement," created when floods wash sand and pebbles down from mountain streamways; wind subsequently blows the dust and sand away, leaving only the stones. These pebble plains have short grass and thin brush. The Chinese learned more than 2000 years ago that pebbles hold in the soil moisture, and thus make good protective cover for fields.

Mountain landscapes range from lush forests in the north to utterly barren, desolate rock piles in the lower desert mountains of the south. Large glaciers exist in the highest ranges, but some of these are now melting. They endured previous cycles of melt around 7000-5000 and again 1000-700 years ago. Many disappeared, to be re-created by the Little Ice Age between 1400-1800. Today they supply vital water to the rivers; this may change in the future.

Mountain conditions in the Eurasian heartland are notoriously harsh and variable over both long-term and short-term time frames. On the other hand, natural selection has done its work, and a truly incredible range of plants have adapted to these conditions. Many of them bear edible fruits and leaves or serve as medicinal herbs. Roger Phillips and Martyn Rix have done yeoman service in comprehensively photo-documenting west and central Eurasian montane plants in a long series of books and articles (see e.g. Perennials ${ }^{7}$; this book has been available online for literally one cent $[\mathrm{sic}]$ ).

A fascinating, now vanishing, component of the desert is desert woodland. This is made up of various shrubs, including tamarisks, wild almond species, and the amazing saksaul, which grows into a large tree on $5 \mathrm{~cm}$ of rain a year. These plants depend on sand dunes to trap and hold water from infrequent rains, also seepage from rivers and streams. They thus colonize dune fields of sand blown from river and lake beds. Always local, desert woodland has rapidly disappeared under human pressure; it is good firewood and the plants are good camel or goat browse.

Also almost gone-or at best grazed into senescense as livestock eat all young trees-are the riparian forests, known as toghai in Kazakh, and by the same or similar words (togai, tugai) in other Turkic languages. These forests of poplar and willow, with understories of oleaster, tamarisk and other trees, once lined the rivers and streams. They were hosts to red deer, wild boar, tigers, and other wildlife. They too have been replaced by cultivation, except in Mongolia, where careful integration of herding with the natural ecosystem has

7 Phillips and Rix (1991), Perennials. 


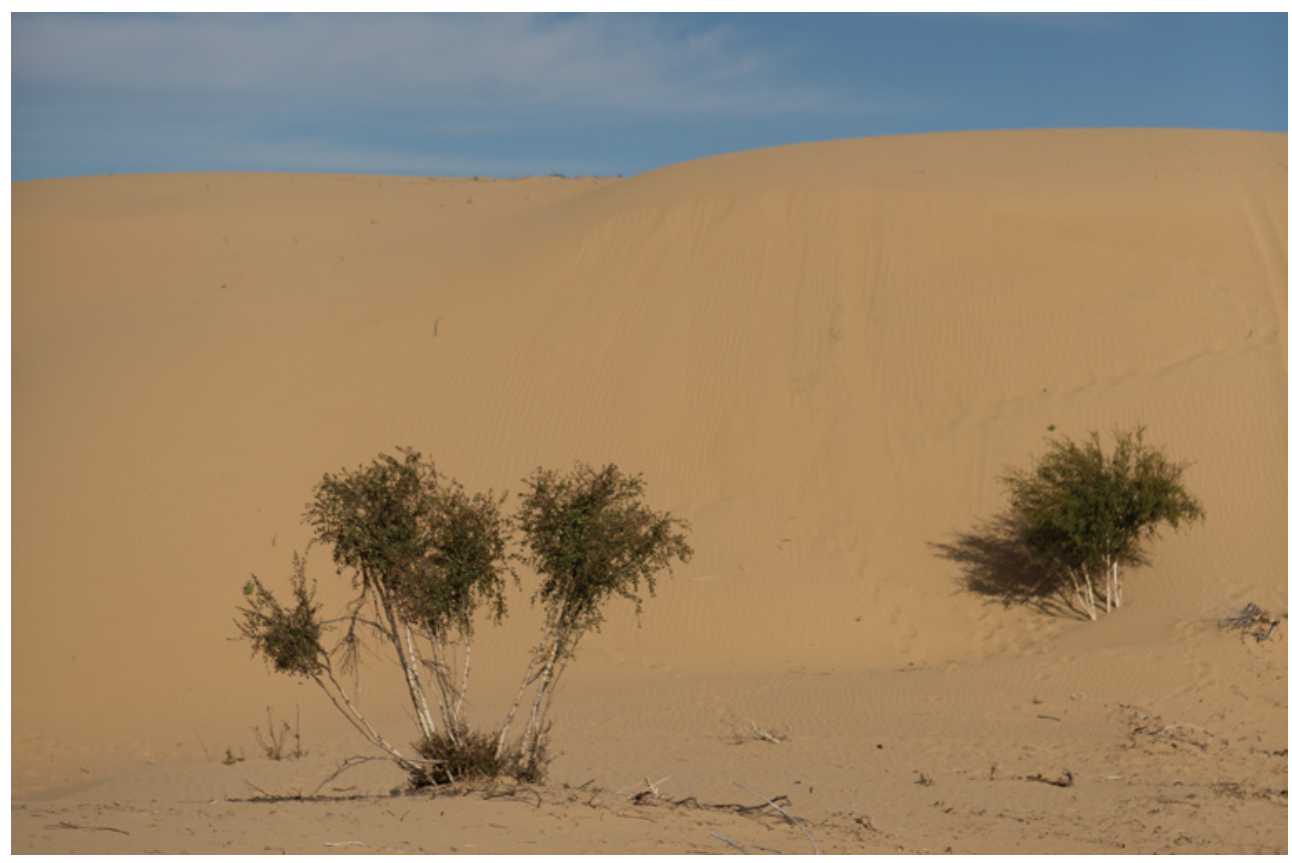

Рното 5 Saksaul

preserved them. Mongolians still revere trees; sacred blue scarves are tied around thousands of riparian poplars, hawthorns, and others, to protect them from being cut down.

Such strips of trees had extremely fertile soil, concentrating the nutrients of the mountains and plains. They also had abundant water, and almost permanent sunny weather. They are thus perfect for agriculture, and today are intensively cropped. Most have been irrigated for thousands of years. Many key innovations in irrigation were made in Central Asia. Most of the rest were made in the Near East, and soon spread to Central Asia. The great Central Asian cities - Samarkand, Bukhara, Khiva, Kashgar and the rest-are all, as a matter of necessity, found in the major river valleys. In no case do these riparian strips cover more than some $10 \%$ of the land. In eastern Kazakhstan and Uzbekistan, however, they are very extensive. Here the main threat is urban sprawl, which is taking out a disturbingly large amount of farmland.

Areas not suitable for agriculture usually support nomad herding, which thus occupies far more of the land, though it supports far fewer people, than farming does. Decline in herding has led to concentrations of former herders in cities, with results often including poverty and overcrowding. Only northern Kazakhstan, the domain of the (formerly) "virgin lands," has extensive rain-fed agriculture. 


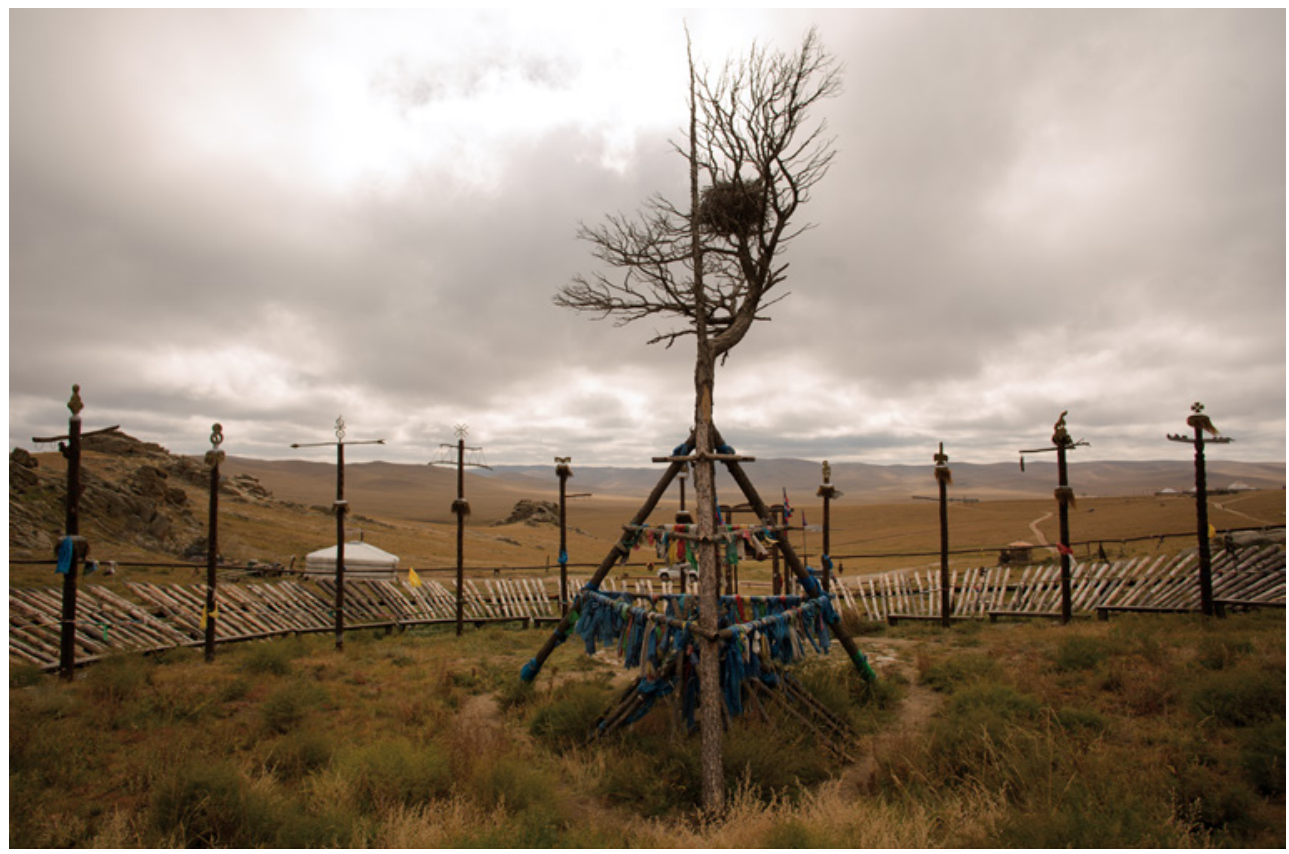

рното 6 Protected tree with cloth

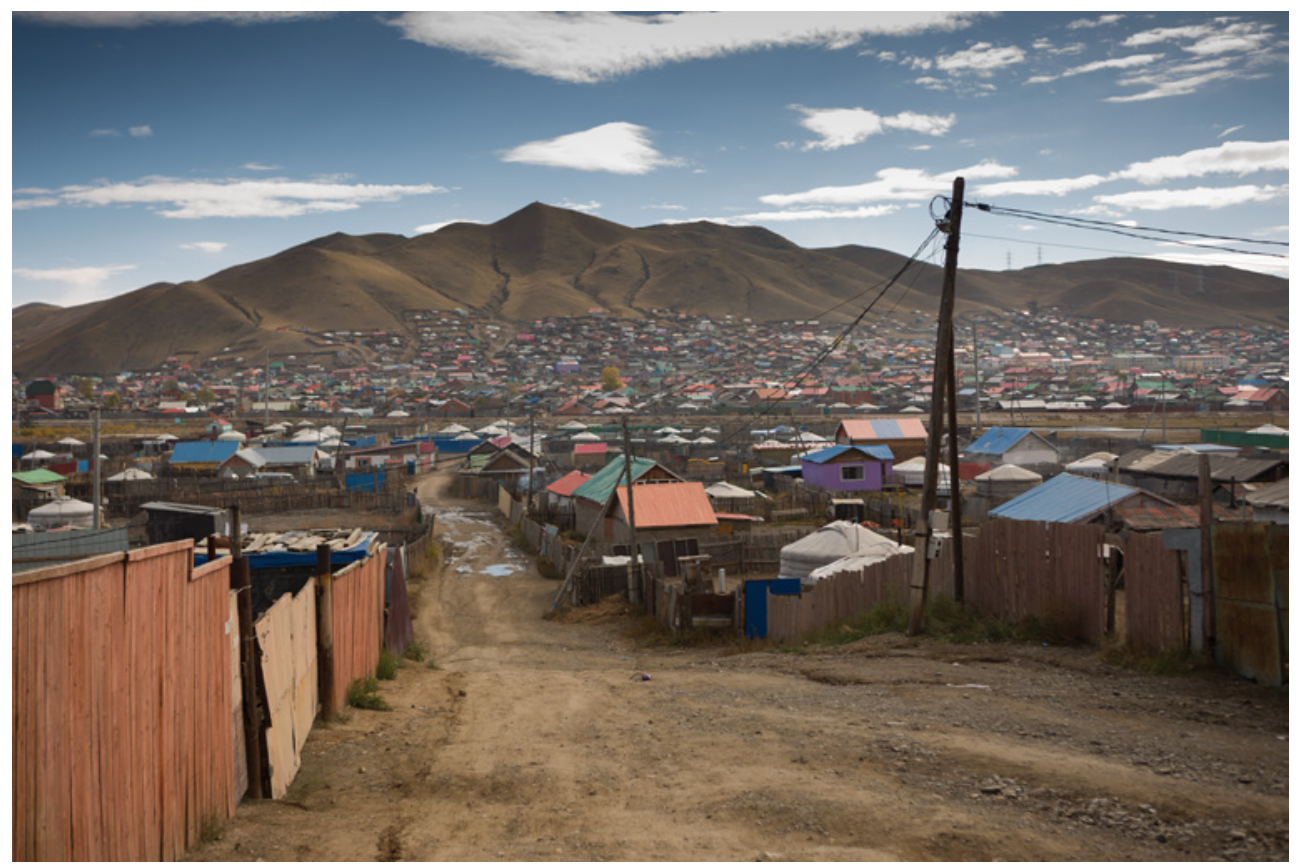

рното 7 The Yurt district in Ulaanbaatar 
Most of the Eurasian heartland has no outlet to the sea. Internal drainage once ended in vast lakes and marshlands. It still does in places where the rivers that feed them have not all, or nearly all, been diverted for irrigation, or in Mongolia used in gold extraction. These wetlands once hosted spectacular fish, waterfowl, and wildlife resources. This includes the mineralized swamp that once was the vast Aral Sea, with its resources of largely fresh water. The deltas of the rivers that feed these internal drainage basins, being among the most fertile and lush riparian lands, support a highly productive agriculture. In much of the area, alas, this has meant cotton monoculture, the cause of the near destruction of the Aral.

An astonishing feature of the Eurasian heartland is the sheer diversity of the vegetation, despite the horrific climate, and the stony, salty, or sandy soils. Those familiar with comparable dry lands in North America and Turkey will correctly expect a fantastic wonderland of spring flowers in the mountain regions. The plants get enough moisture from melting snow to put on a dramatic flush of growth, followed by a mad competition for the pollinators available. Then the plants die or go dormant for the year. Many have evolved to survive by means of underground storage structures, so Central Asia is a great storehouse of bulbs, corms, and other "root" resources that are often edible.

More relevant to foodways are the many medicinal herbs, ${ }^{8}$ and wild fruits. Apples certainly come from the Eurasian heartland; they have been genetically traced to southeast Kazakhstan, near the modern city significantly named Almaty, "father of apples," although the name is popularly said to go back to a Russian equivalent of Johnny Appleseed in the 19th century. Apricots, peaches, walnuts, and almonds are native, and local stock probably contributed to domestic forms. All are good eating, as are the local fruits such as alpine wild strawberries, the celebrated büldirgen (Fragaria vesca). Less familiar to the outside world is sea buckthorn (Hippophaë rhamnoides, the Mongol chatsargana), a wonderful-flavored yellow fruit and medicinal herb of the colder parts of the region. ${ }^{9}$

The importance of trees in Asia is shown by the widespread tree worship. Virtually everywhere in Asia that is not solidly Muslim or Christian, there is a high religious and spiritual regard for trees. Throughout the Eurasian heartland, vitally important religious regard keeps trees alive and flourishing. Even

8 Eisenman, Zaurov, and Struwe (2013), Medicinal Plants of Central Asia: Uzbekistan and Kyrgyzstan, trans. Zaurov, Eisenman, Yunusov, and Isaeva; Boldsaikhan (2004), Encyclopedia of Mongolian Medicinal Plants.

9 Tungalag and Jamsran (2012), A Field Guild to the Trees and Shrubs of Mongolia/Mongol Orni Zarim Mod, Söög Tanikh Garin Avlaga. 


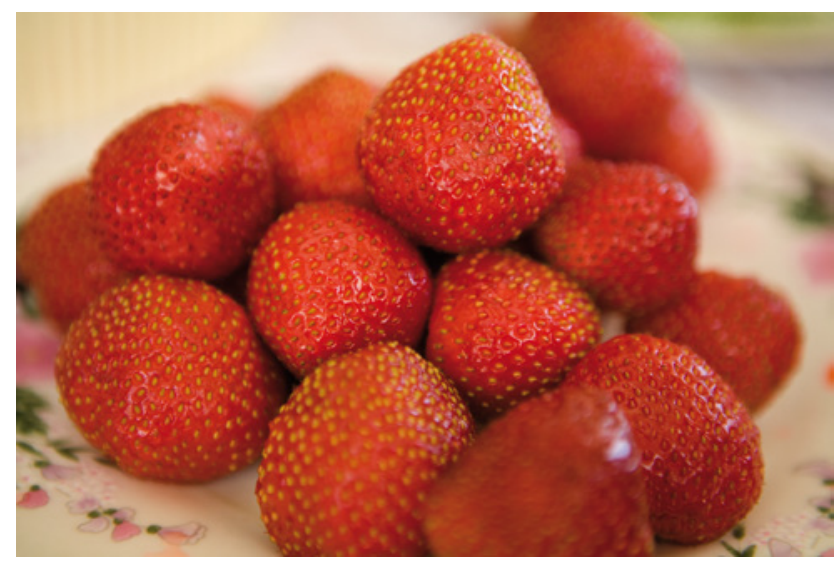

Рното 8

Büldirgen

in areas that are now Muslim, ${ }^{10}$ or Christian, ${ }^{11}$ there are many survivals of the ancient religion, except where modern extremism has entered. The Russian scholar Olga Gorshunova ${ }^{12}$ reports sycamores up to three meters thick being venerated; they were locally held to be protected, and honored with flags, ribbons, and protective fences. She notes similarities to ancient Sumerian tree cults, and we can certainly see similarities to Chinese ones.

In Mongolia, where there are not so many trees, the landscape is dotted with ovoo (obo in earlier pronunciation), rock cairns sometimes built up with and frequently covered with cloth offerings. Ovoo celebrate the spirits and mark particularly beautiful plots or other places where the spirits are likely to congregate.

The climate is no less a threat than the landscape. Winter cold is brutal, often down to Arctic levels. Frederick Burnaby's classic 19th-century account A Ride to Khiva (1876) gives a harrowing account of his nearly losing his hands because he failed to put on heavy mittens over his already heavy traveling gloves. The Arab traveler Ibn Fadlān (born 877), writing almost a millennium earlier, provides a very similar account. In the northern portions there occurred the dreaded ice-storms called $d z u d$ in Mongolian (also transliterated zhud or dzuud; in Kazakh and other Turkic languages jut), when masses of snow or late wet snow or sleet can cover the grazing and form an icy, impenetrable sheet over everything (Mongolian qara dzud, "black dzud") or just snow

10 Gorshunova (2012), "Pray, Howl and Take My Power: Sacred Images and Nature Cult in Central Asian Islam," Presentation, International Society for the Study of Religion, Nature and Culture, Malibu CA, Aug. 9.

11 Shutova, “Trees in Udmurt Religion," Antiquity 8o (2006), 318-327.

12 Gorshunova, ,"Pray, Howl and Take My Power." 


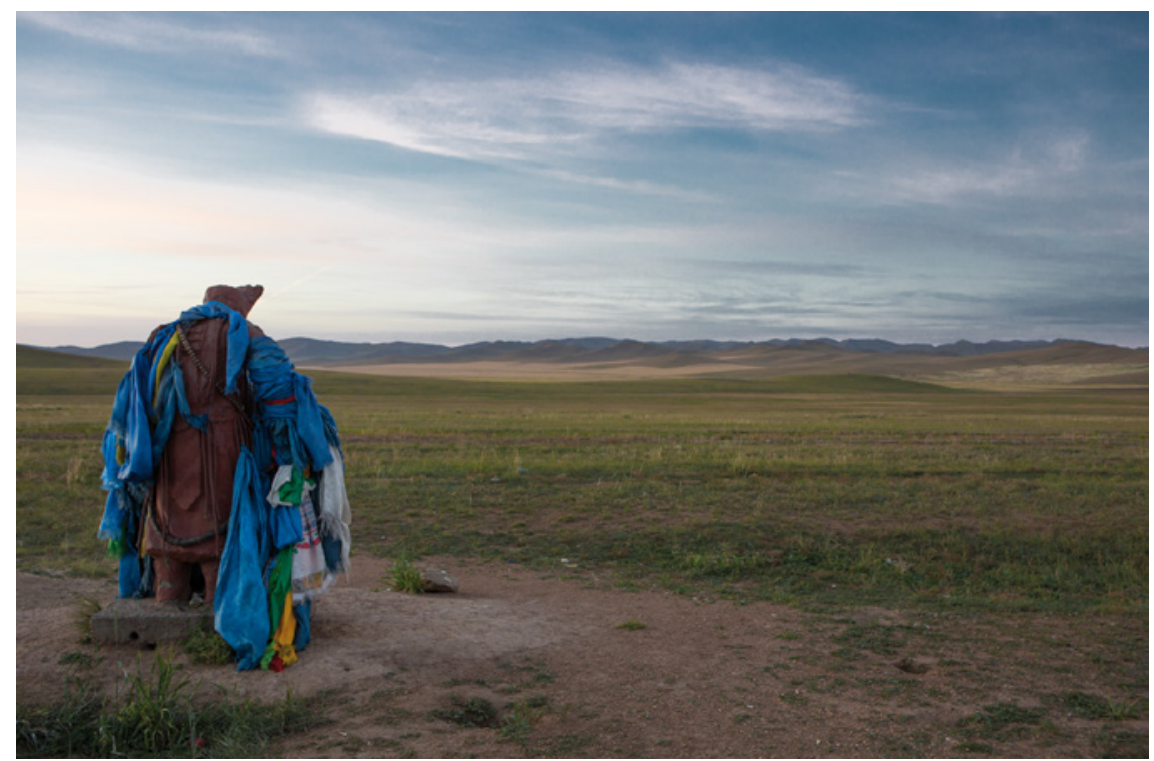

Pното 9 An Ovoo

too deep for animals to paw through (Mongolian chaghan dzud, "white dzud"). Such an event still means mass death for livestock and starvation for herders. "In Mongolia in 2008-9 a period of drought followed by an unusual cruel winter (a $d z u d)$ killed eight million animals." ${ }^{3}$

Summer temperatures in such lowlands as the Turpan Depression are among the highest in the world, comparable to Death Valley and the Sahara oases. In the Helmand lowlands of Afghanistan, temperatures up to $45 \mathrm{C}$ (120 F) have been recorded at midnight in June; yet freezes can occur as early as September. The Helmand is also blessed with the "Wind of 120 Days," which resembles the Santa Anas of southern California: a blazing, bone-dry, downvalley wind, up to over $140 \mathrm{~km} / \mathrm{hr}$, that uproots trees and drives dust storms. ${ }^{14}$ Santa Anas usually last only a few days, and the thought of one that lasts $120-$ late summer and much of fall-is staggering. Genial, moderate climes are nowhere found. Temperatures in desert mountain valleys can change over 20 degrees $\mathrm{C}$ in a single day. ${ }^{15}$

13 Cunliffe, By Steppe, Desert, and Ocean, 8; Ibn Faḍlān (2012), Ibn Faḍlān and the Land of Darkness: Arab Travellers in the Far North, 8-9.

14 Dupree (1980), Afghanistan.

15 Nabhan (2014), Cumin, Camels and Caravans, 148. 
With its geographical diversity and many environmentally rich areas, the Eurasian heartland once hosted a vast amount of wildlife. It was notable especially for herds of thousands of gazelles, and up to millions of saiga antelope. Wild Bactrian camels, wild asses (onagers, kiangs), red deer, wild boar, mountain sheep, gazelles, wild horses, and other animals occurred in vast numbers. There were - and still are — masses of domesticated livestock everywhere; this includes mostly sheep and goats, but also thousands upon thousands of horses in Mongolia and Kazakhstan, used as a source of meat as well as for riding. V. M. Masson points out that "the fauna...is characterized by a large number of fast-moving animals which can rapidly travel great distances in search of waterholes." ${ }^{6}$ Their young must be able to run a few hours after birth, to escape predators.

Hunting was once a major subsistence activity. Hunting is an understudied aspect of Central Asian food, as is the gathering of wild resources. We know that humans managed to hunt, kill, and butcher a mammoth as early as 45,000 years ago in Siberia. ${ }^{17}$ Hunting continues today, although depletion of game, fish, and even wild plants in the last two centuries has made it a marginal part of life. People had to compete with wild predators: leopards in the lowlands, tigers wherever there was forest, snow leopards in the high peaks, and wolves everywhere. Flocks of mountain sheep were common in the mountains. Fish thronged the few rivers and the great lakes. Birds abounded in incredible numbers, especially during migration, when the tens of millions of birds that nested in Siberia moved to or from winter quarters in the warm South.

Hunting is less prevalent today, though it continues. The Kazakhs still list the necessary accoutrements of a warrior as including a hunting hound (tazy), hunting eagle (byrkyt or bürkit), and snare, listed along with horse and beautiful wife! Kazakh, Kyrghiz, and Mongol herdsmen use great and powerful hunting eagles, falcons, and even owls to hunt a variety of animals. This includes wolves, a tabu animal for Kazakhs and some other Turkic groups to take directly; their origin story holds that the Turkic peoples are descended from a wolf. Falconry may have originated in Inner Asia. ${ }^{18}$ Such hunting provided not only food and spectacle, but also fur for clothing and trade. Hunting foxes for their fur, with the aid of golden eagles, is still a custom in the wildest parts of

\footnotetext{
16 Masson (1992), “The Environment."

17 Pitulko, Tikhonov, Pavlova, et al., "Early Human Presence in the Arctic: Evidence from 45,ooo-year-old Mammoth Remains," Science, Vol. $35^{1}$ (2016), 26o, doi: 10.1126/science. aado554. 
the region. (Imagine being tough enough to have a golden eagle land on your arm-leaving aside the skill needed to train and manage such a bird. The sheer momentum of the bird's landing can knock a strong man into the dust.) Predator control was also involved, since the eagles are sometimes flown at wolves by the Kazakhs to remove the stain of a human killing a wolf, a major issue in traditional society.

Kazakhs even lack a word for wolf. The commonly used one, qasqyr, is a tabu word, "gray worm." Such nervousness about saying the true name of a dangerous animal is universal in Eurasia; tigers are often similarly euphemized. (The same logic gave us, in Germanic languages, "bear" and its cognates-from an old root for "brown" - instead of the expected cognate of ursus and arctos.)

As so often, Marco Polo said it best: ... when the "the great lord goes birding with his gyrfalcons and other birds, there are a good 10,0oo men, arranged 2 by 2 , who are called toscaor, ${ }^{19}$ which in our language means "men who stand guard" ... Each one has a falconer's whistle and a hood, so that he can call and hold the birds." ${ }^{20} \mathrm{He}$ continues: "there are also a great number of eagles trained to catch wolves, foxes, fallow deer and roebucks, and catch a good many of them. But those trained to catch wolves are very large and very powerful, for know that no wolf is so big as to escape being taken by these eagles."21 In Shangdu 上都 (the summer capital that Samuel Taylor Coleridge immortalized under the Portuguese spelling of Xanadu) Marco notes the gyrfalcons and falcons were kept in cages and, he says: ..."there are more than 200 gyrfalcons."22

In more modern times, kings flew eagles and gyrfalcons. The nobles preferred peregrine and saker falcons, and the court ladies might train rosy starlings to hawk for butterflies! Modern Mongols today commonly use owls to hunt, as well as eagles and hawks of every sort. Little has been forgotten.

Writings on hunting are scarce from Central Asia, thus of major importance is Thomas Allsen's study The Royal Hunt in Eurasian History, and, more recently, the specialized work on falconry by Ulambayaryn Erdenebat (Ulaanbaatar, 2014). No doubt Central Asian royal hunts were as complex as they were elsewhere, with much special terminology and manners, as the accounts of Marco Polo and other witnesses make clear.

This world persisted until the coming of high-powered rifles, and modern landscape alteration through agriculture and mineral extraction. Now, the

19 This is tutqa'ul, an official manning a watch station associated with the postal system, a transportation policeman. See Buell and Fiaschetti (2018), Historical Dictionary of the Mongol World Empire and its Successor States, 298.

$20 \quad$ Kunoshita, trans. and ed. (2016), Marco Polo, the Description of the World, 83.

21 Kunoshita, Marco Polo, 82.

22 Kunoshita, Marco Polo, 64. 


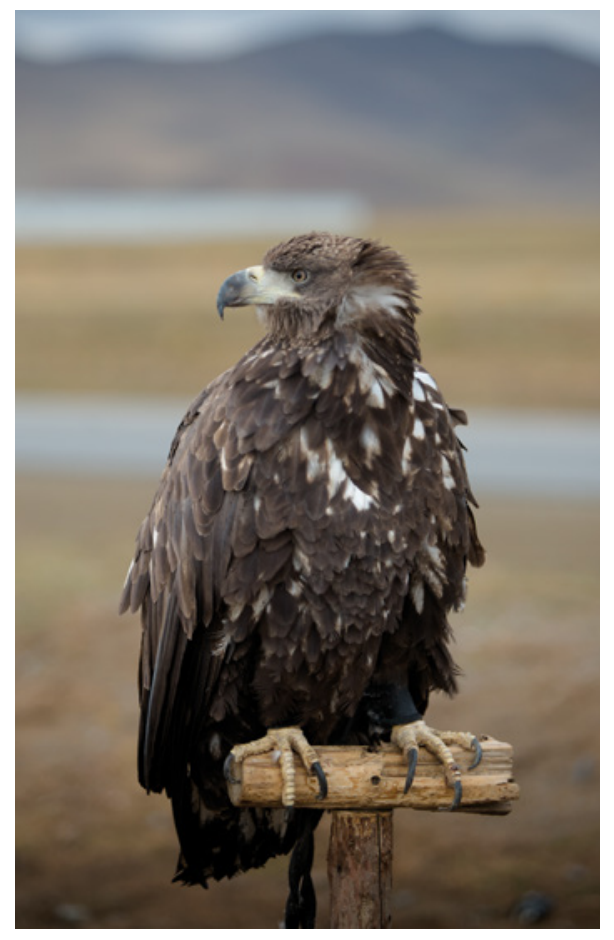

Pното 10

Mongol hunting bird

saiga antelope is desperately endangered. One third of the few survivors were killed by a respiratory epidemic in 2015. Horses are extinct in the wild except for a few recently-reintroduced Przhevalsky's horses in Mongolia. There are still a few feral horses on Jeju Island, Korea, left over from the 13th century Mongol invasions of Japan. Fish have disappeared with the drying of lakes, overuse of most rivers and overfishing in the few rivers that still have livable conditions for them. Thus, few writers could observe a hunting way of life. Those early travelers who could observe it were quick to emphasize its importance. Thomas Allsen, and Richard Almond in Medieval Hunting, ${ }^{23}$ have combed this literature; they show how important hunting was not only for food, but to train nobles for war, to demonstrate royal power, and to establish royal charisma through vast impressive spectacles.

The inhabitants of the Eurasian heartland certainly agreed with the Elizabethan English author who wrote that: "...he cannot be a gentlemen [sic] which loveth not hawking and hunting... The like saying is that he cannot be a gentleman which loveth not a dog" (anonymous author in 1568, quoted by Richard

23 Allsen (2006), The Royal Hunt in European Prehistory; Almond (2003), Medieval Hunting. 
Almond). ${ }^{24}$ Everywhere, hunts were highly ritualized and very much an extended social activity. Qubilai-qan (r. 126o-1294) took much of his court with him when he went hunting-even his court ladies. He also took his birds and even hunting leopards or cheetahs (bars) - the latter trained to perch on a horse. A famous Chinese painting shows just such a hunting leopard.

Most spectacular indeed were the royal hunts. These produced, if our sources may be believed, hecatombs of game, which fed the court and often many ordinary people. The sizes of the takes from these hunts must be highly exaggerated, for the environment would simply not sustain hunting at that level, and the Mongols and their courtiers were too savvy to destroy it by overhunting. They wanted to come back for later hunts.

Game obviously entered into the elite medieval diet in Central Eurasia on a vast scale, as is witnessed, in particular, by the many wild game recipes found in the Yinshan zhengyao 飲膳正要. "Proper and Essential Things for the Emperor's Food and Drink" (YSZY), the official Yuan 元 Dynasty dietary manual and presented to the court in 1330. One of these recipes, an appropriate first recipe for our book, even calls for cooking a wolf. Hu Sihui 忽思慧, the court dietitian, and main author of the text who was probably an Uighur, has even assigned the wolf suitable medical qualities. The spices mark this as an adaptation of a lamb recipe. A qian 錢 is a Chinese ounce:

\section{Roast Wolf Soup}

Ancient pencao 本草 [herbals] do not include entries on wolf meat. At present we state that its nature is heating. It treats asthenia. I have never heard that it is poisonous for those eating it. In the case of the present recipe, we use spices to help its flavor. It warms the five internal organs and warms the center.

Wolf meat (leg; bone and cut up), tsaoko cardamoms (three), black pepper (five qian), kasni (one qian), long pepper (two qian), grain-of-paradise (two qian), turmeric (two qian), za'faran (one qian).

Boil ingredients together into a soup. Adjust flavors of everything using onions, sauce, salt, and vinegar. ${ }^{25}$

Birds exist in great variety in Central Eurasia. Birds concentrate their urine and find other ways to conserve moisture as well, and thus can flourish in deserts.

\footnotetext{
$24 \quad$ Almond (2003) 33.

$25 \mathrm{Hu}(2010)$, Yinshan zhengyao, Sibu congkan xubian 四部叢刊續編子部, I, 36A-B; Buell and Anderson, with Perry (2010), A Soup for the Qan: Chinese Dietary Medicine of the Mongol Era as Seen in Hu Sihui's Yinshan Zhengyao, 286-87.
} 


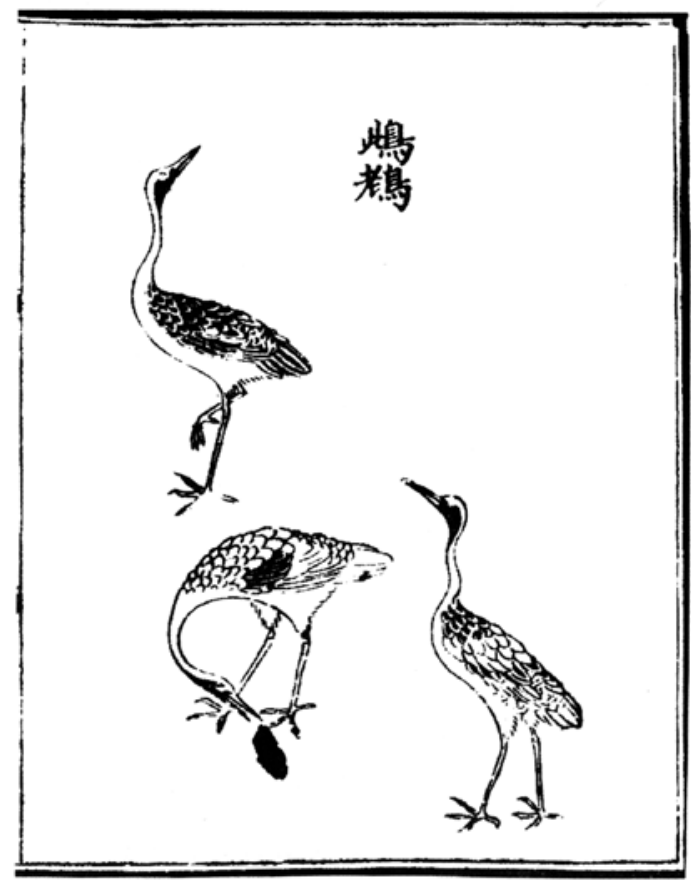

FIGURE 1

Cranes (YSZY, III, 23A). Shown are the "White Crane," the "Black-headed Crane," and the "Iranian Crane," Grus leucogeranus, G. nigrocollis, and G. grus respectively

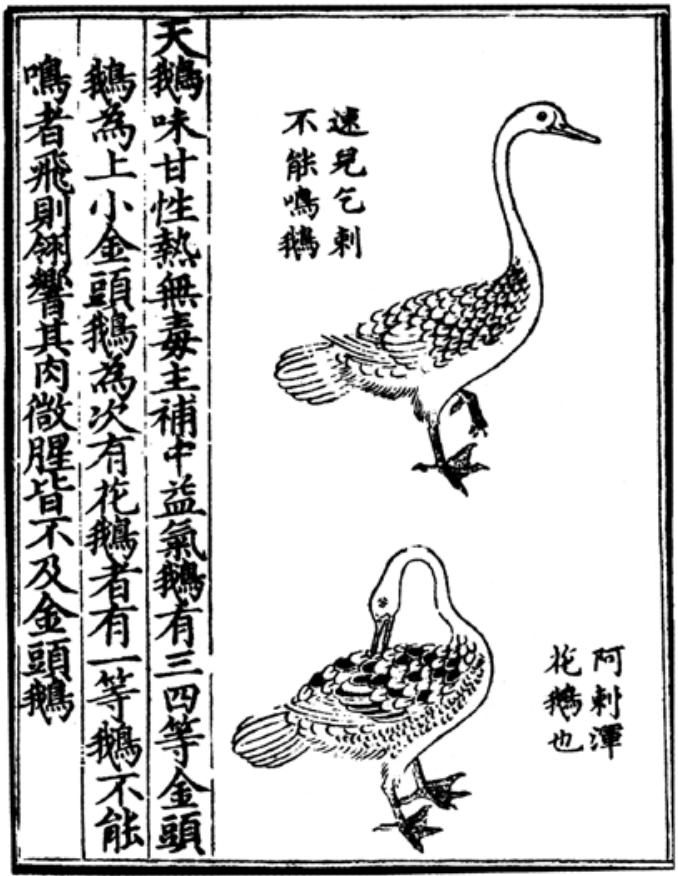

FIGURE 2

Swans (YSZY III, 21B). Shown are the Yeke siraqun qun, "Greater

Golden-headed Swan," Cygnus cygnus, the Surqyl, the Mute swan, Cygnus olor, and Alaq qun,

"Variegated Swan," unidentified 
Recently, overgrazing, and conversion of wildlands to intensive agriculture have greatly reduced their numbers. The Eurasian heartland was a world center of eagles and falcons, and of vultures the size of condors. Water birds and bustards provided good food. Cranes were common enough for Marco Polo to describe, obviously from experience, several species. (His detailed, accurate accounts of them are one of the proofs that he actually traveled where he said he did. ${ }^{26}$ ) All are rare or endangered now. Birds also appear, along with wolves and other large animals, in the YSZY, including cranes and swans, the latter named in transliterated Mongolian, and some shore birds, all presumably hunted and eaten (Figures 1-3):

Small mammals were also hunted and included a wondrous variety of marmots, jerboas, ground squirrels, hamsters, and other rodents, as well as pikas (rock rabbits). Every major mountain range has its own species of marmot and pika. The rodents contributed importantly to history by being the definitive hosts of the bubonic plague. How it got to Europe is still a bit of a mystery. In the Plague of Justinian (541-542), and the far worse Great Plague of 1346-1350, and in many smaller but still savage later epidemics, it changed history profoundly. Despite speculative claims to the contrary, it is not known to have caused similar epidemics in China; the plague ecology of eastern Asia is different enough to have kept it a minor endemic rather than a disastrous epidemic. ${ }^{27}$ Within Central Asia itself, nomads knew enough to avoid sick rodents, even if outbreak years could not be avoided entirely. Such years could occur several poor years leading to a die-off of predators were followed by suddenly improved conditions that allowed rodent populations to explode before predators like wolves could catch up.

Sadly, increasing "modernization," whether it has been Christian, Islamic, communist, or merely economic, has been deadly to animal conservation, and to other kinds of preservation of nature. It has changed the basic character of the culture, and even geography of the Eurasian heartland. Whatever "progress" may have come from these modern ideologies, they have been intensely regressive in this regard. Comparison with Mongolia, the last refuge of traditional attitudes to the environment, confirms the general finding that early and local Asian religions were aware of the values of forests, wildlife, clean water, and other environmental benefits, ${ }^{28}$ while today's modern ideologies are almost totally destructive. Fortunately, enough traditional attitudes survive

\footnotetext{
26 Haw (2006), Marco Polo's China: A Venetian in the Realm of Khubilai Khan; E. N. Anderson, "Birds of the Mongol Empire," Ethnobiology Letters 7:1 (2016), 67-73.

27 Benedict (1996), Bubonic Plague in Nineteenth-Century China; Buell, "Qubilai and the Rats" Sudhoffs Archiv, Band 96, 2 (2012), 127-144.

28 Anderson (2010), "Indigenous Traditions: Asia," 216-221; Anderson (2014), Caring for Place.
} 


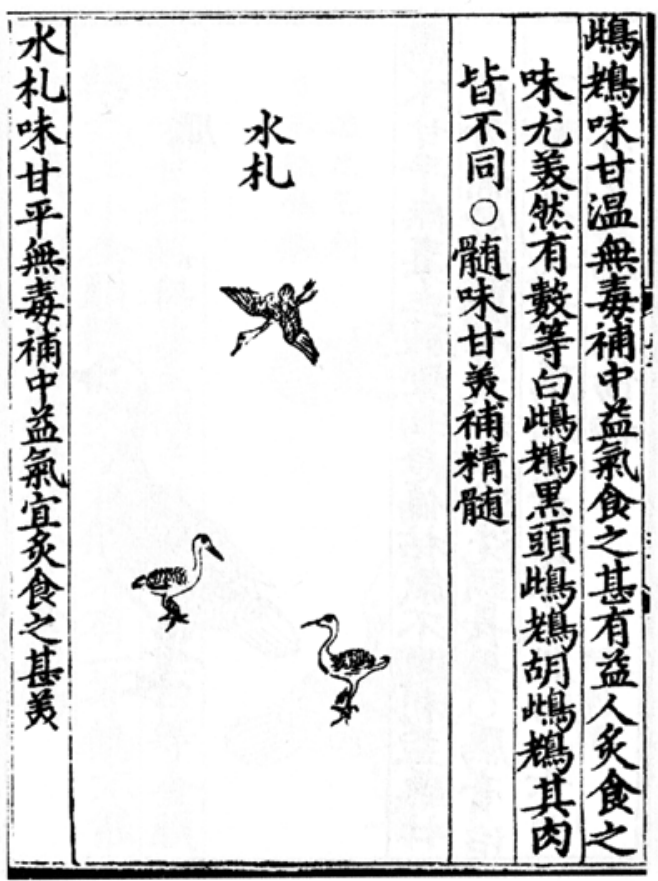

FIGURE 3

Shore birds (YSZY, III, 23B)

in much of the region to give the worldwide environmental movement some traction. The collapse of the USSR has proved devastating in the Central Asian republics. Local greed, corruption and crime have since run rampant. Parks were ravaged, carefully restored game populations shot to extinction, public works allowed to fall apart. Repairs have, however, begun, and the more progressive Central Asian nations are reasserting their traditional conservation ethics.

The most dramatic bit of ruin has concerned the Aral Sea. ${ }^{29}$ It was once a vast body of inland water with a rich fishery, including its own varieties of sturgeon. In the USSR days the rivers feeding the Aral water were divered to irrigate cotton fields. Salts flooded into the sea from salt flats left behind after the retreat of the rivers, and land and water became saturated with deadly toxic pesticide and herbicide residues carried by the river water. The water table sank. This meant that more and more water was needed to irrigate and replenish the Aral basin. More water, in turn, meant more minerals in what water there was, and tended to concentrate pesticide and herbicide runoff. The level of the sea

29 Kobori and Glantz, eds. (1998), Central Eurasian Water Crisis: Caspian, Aral, and Dead Seas. 


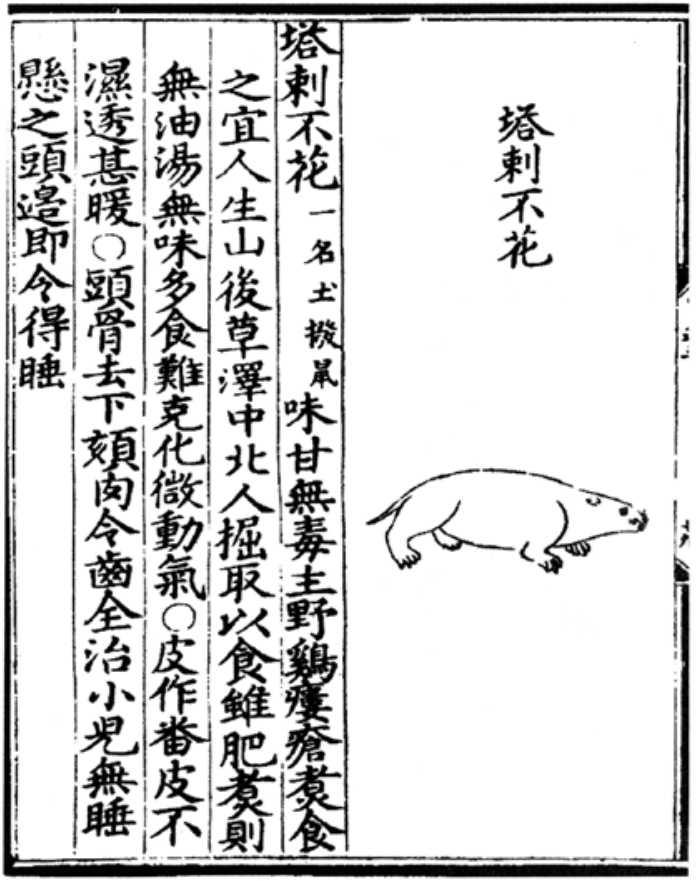

FIGURE 4

The Tarbaqan marmot (YSZY, III, $19 \mathrm{~B})$

sank drastically, leaving mineralized sea bottoms. Over the years, the Aral Sea shrank to a few small lakes too salty for fish. Misuse of the remaining water flow since then has not helped.

Today Turkmenistan, Uzbekistan, Kyrgyzstan, and Tajikstan freely take the water of the Aral Sea's main feeder river, the Amu Darya. Though a huge river, the waste of water is so enormous that the flow no longer reaches the Aral. The four countries are, respectively, the first, fourth, fifth, and seventh largest users of water per capita in the entire world. (The other top countries are Iraq and Guyana, dependent on irrigated farming, and the notoriously water-profligate United States.) Yet the incomes of these nations (and of Afghanistan, which also depends on the Amu Darya) are all very low, meaning that the five are almost unique in the world in use of water per dollar of GNP; only impoverished, rice-dependent Madagascar and Guyana are competitive. ${ }^{30}$

Kazakhstan, where environmentalism has become a significant force, has somewhat restored its part of the sea, complete with a few fish species ${ }^{31}$. The larger Uzbekistan portion is now almost completely dry, having dramatically shrunk during the summer of 2014. This has created vast salt flats with little

30 Varis, "Curb Vast Water Use in Central Asia," Nature 514 (2014), 27-29.

$31 \quad$ Micklin and Aladin, "Reclaiming the Aral Sea," Scientific American, April (2008), 64-71, with update from satellite photographs on google maps. 
hope of recreating the sea even if the resources were available to do so. Uzbekistan is trapped; having largely destroyed all other sources of wealth, it depends on cotton, the main source of the Aral's problems, for economic survival. The Aral and associated regional problems remain one of the world's most chilling lessons that those who "struggle against nature" (in Mao Zedong's famous phrase) must inevitably lose in the long run. The whole episode proves man's capacity to change not only the physical environment but even the climate. The area once enjoyed a climatic moderation due to proximity to the water of the Aral Sea. It is now colder, with longer-lasting winters.

Despite such catastrophies, there is hope. Conservation is far from dead in the ex-USSR nations, and has been sporadic but locally effective in parts of Chinese Central Asia. Mongolia is a relative success story, even with modern overgrazing around Ulaanbaatar and a few other places. Mining threatens this, but so far wild vegetation and animal life still flourish. Current protection has allowed the successful reintroduction of the wild horse, among other projects. Environmental awareness continues to grow in Central Asia, to a great extent because of resurgent traditional values among Turkic and Mongol peoples.

\section{Nations of Today}

The Eurasian heartland is part of the great Eurasian land mass, and both geography and early history make it, and not Asia the continental unity. Asia is very much a construct. Only an ingrained Europocentrism and habit have justified separating "Europe" as a separate continent, in contradistinction to Asia.

The heartland is a unified region geographically, and to an extent historically, but it has rarely been a political unit. The Mongols conquered it, and Tamerlane conquered much of it; otherwise it has been a battleground for contending polities, often based far outside the region. This tendency climaxed in the 19th-century rivalry of Russia and Britain. At the same time, the Ottomans in the West, and the Qing 清 Dynasty in China, vied for influence. The will of the inhabitants of the area was not even considered, except as something to break; the Qing went so far as to wipe out the Dzungar people in an 18thcentury genocide. ${ }^{32}$ At times, the Eurasian heartland was split into many small polities, which were at times mere city-states, constituting little more than a dense settlement and an associate oasis and water source. Ancient and medieval ancestors indulged in endless petty rivalries. This history calls into question the conventional Europe-based wisdom that a region divided into many little polities is bound to progress.

Perdue (2005), China Marches West. 


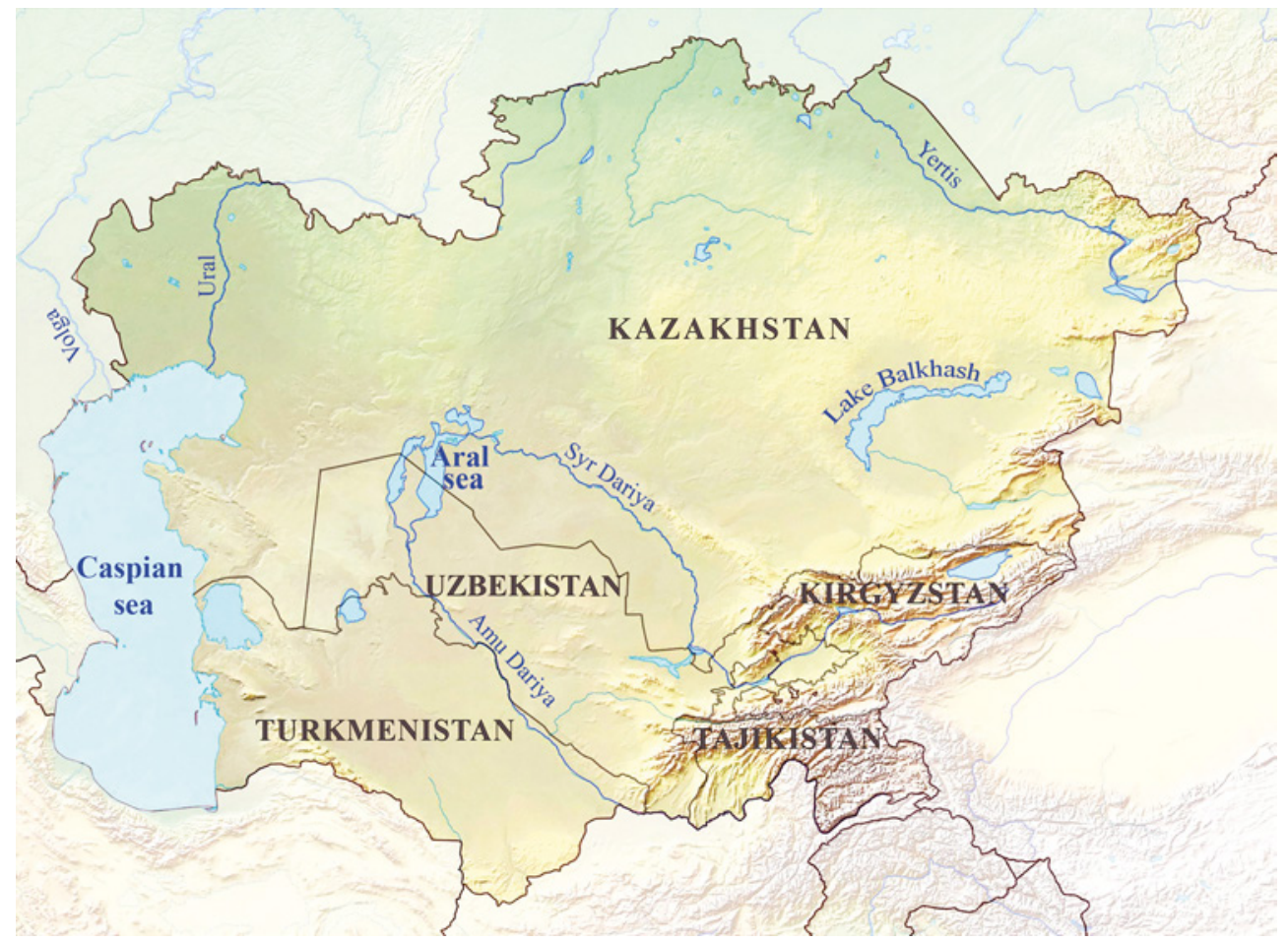

MAP 2 Kazakhstan and its neighbors

Agriculture and Environment

The world of the Eurasian heartland is famously divided between "the desert and the sown." The quote derives from Omar Khayyam's Ruba'iyat, as translated by Edward Fitzgerald:

With me along the strip of Herbage strown

That just divides the desert from the sown ... ${ }^{33}$

Khayyam came from Nishapur in northeast Iran. Although Nishapur lies just outside our politically-defined region of the Eurasian heartland, it remained part of it ecologically.

His "strip of herbage," the driest bit of watered land, lying just beyond the outermost irrigation canal, was the home of the migrant stockraisers. It divided steppes, deserts, and mountains from intensively cultivated river and lake

33 Khayyam (1900), The Rubáiyát of Omar Khayyam, trans. FitzGerald, 97. 
TABLE 1 The modern nations of the Eurasian heartland and the associated areas of China (some figures are approximate and are from the 2019 World Almanac and Book of Facts, New York, 2019)

\begin{tabular}{|c|c|c|c|c|}
\hline Nation & Area (sq km) & Population & Density & $\%$ Arable \\
\hline Afghanistan & 652,230 & $34,940,837$ & 53.6 & 11.9 \\
\hline Kazakhstan & $2,724,900$ & $18,744,548$ & 6.9 & 10.9 \\
\hline Kyrgyzstan & 199,951 & $5,849,246$ & 30.5 & 6.7 \\
\hline Mongolia & $1,564,116$ & $3.103,428$ & 2.0 & 0.4 \\
\hline Tajikistan & 143,100 & $8,6 \circ 4,882$ & 60.8 & 6.1 \\
\hline Turkmenistan & 488,100 & $5,411,012$ & 11.5 & 4.1 \\
\hline Uzbekistan & 447,400 & $30,023,709$ & 70.6 & 10.1 \\
\hline \multicolumn{5}{|c|}{ Chinese provinces: } \\
\hline Inner Mongolia & $1,183,000$ & $\begin{array}{l}25,050,000 \\
\text { (2014 est.) }\end{array}$ & 20.2 & $>10$ \\
\hline Xinjiang & $1,664,900$ & $\begin{array}{l}22,980,000 \\
\text { (2014 est.) }\end{array}$ & 13.0 & $>5$ \\
\hline Gansu 甘肅 & 425,800 & $\begin{array}{l}25,640,000 \\
(2011)\end{array}$ & 6o.o & $>10$ \\
\hline Totals & $9,492,497$ & $180,035,661$ & & \\
\hline United States & $9,826,675$ & $329,256,465$ & 36 & 16.6 \\
\hline
\end{tabular}

Note that some of the countries have high population densities, while others are very low. The United States provides comparison, being about the same size as the region.

valleys. "The Strip of Herbage" was thus a very important area, even if economically not so significant as the "sown."

For 7,000 years, agriculture in the better-provided areas of the Eurasian heartland has meant primarily barley and wheat. Other grains-millet, sorghum, and (post-Columbian) maize-are minor back-up crops, often are grown for animals. Various vegetables and spices have remained minor crops. Cotton has long been the fiber crop and a commercial mainstay. Grapes are important, but since Islam in theory forbids alcohol, the large wine industry of ancient times has given way to table grape and raisin growing. Melons are 
important, and their quality is world-famous; the dry air, along with the contrast of hot days and cold nights cause excellent flavor to develop.

The most distinctive thing about heartland agriculture is the extreme importance of tree crops. Apricots, apples, cherries, plums, peaches, mulberries, pomegranates, and other crops are very widely grown. Walnuts are grown in mountain areas where water is available, largely in the south-central parts of the region. Many communities subsisted heavily on tree crops; some even relied on them more than on grain. Unfortunately, the escalation of war, and development of military technology, has led to scorched-earth tactics on a mass scale in many areas in the last two centuries. This has destroyed many highly productive orchards in war-torn areas like Afghanistan. Orchards take years to come into bearing, whereas grain can be ready in a few months. Thus, large-scale scorched-earth war often leads to rapid replacement of tree cropping by grain. Comparing travel accounts from the 18th and 19th centuries with the situation today makes this clear. So does the modern tendency to bring back "food forests" by planting dooryard and street trees that bear fruit. In Tashkent, for instance, the destruction of the city by an earthquake in 1966 led to rebuilding as a "green city," with many of the trees being mulberries-the rain of pavement-staining fruits in May being welcomed. In any case, a characteristic of Central Asian food-derived from the early Near East-is use of fruit in meat dishes. Almaty, similarly afflicted by earthquakes in the 19th century, supposedly required young men to plant 15 trees (per man) before getting married $^{34}$; the present cityscape indicates that many of these were apricot, mulberry, apple, cherry, and plum. Apricots and raisins, especially, find their way into pilafs and stews. Iranian influences include use of barberries and pomegranate seeds as well.

Agriculture in the heartland, where possible, usually demands irrigation. The agricultural valleys are usually long and thin, following rivers. Some are wide, and here the great cities arose. Others are so narrow that only one or two fields can be irrigated from the rivers. The rivers drain mountains whose rainfall is often so erratic and uncertain that the water one year may almost fail, and the next year may cause major flooding. ${ }^{35}$ This explains the rather scattered appearance of cultivation in some of the less heavily managed and more erratic river drainages. Inspecting satellite photographs of the Syr Darya valley (draining west into the Aral Sea), for instance, shows many temporary marshes, cutoffs, and salt flats. Cultivation is limited to securely irrigable and nonsaline areas. Fertile if isolated mountain valleys give way to a long and narrow

34 Brummell (2018), Kazakhstan, 109 .

35 Brite (2011), "The Archaeology of the Aral Sea Crisis," 13-14. 


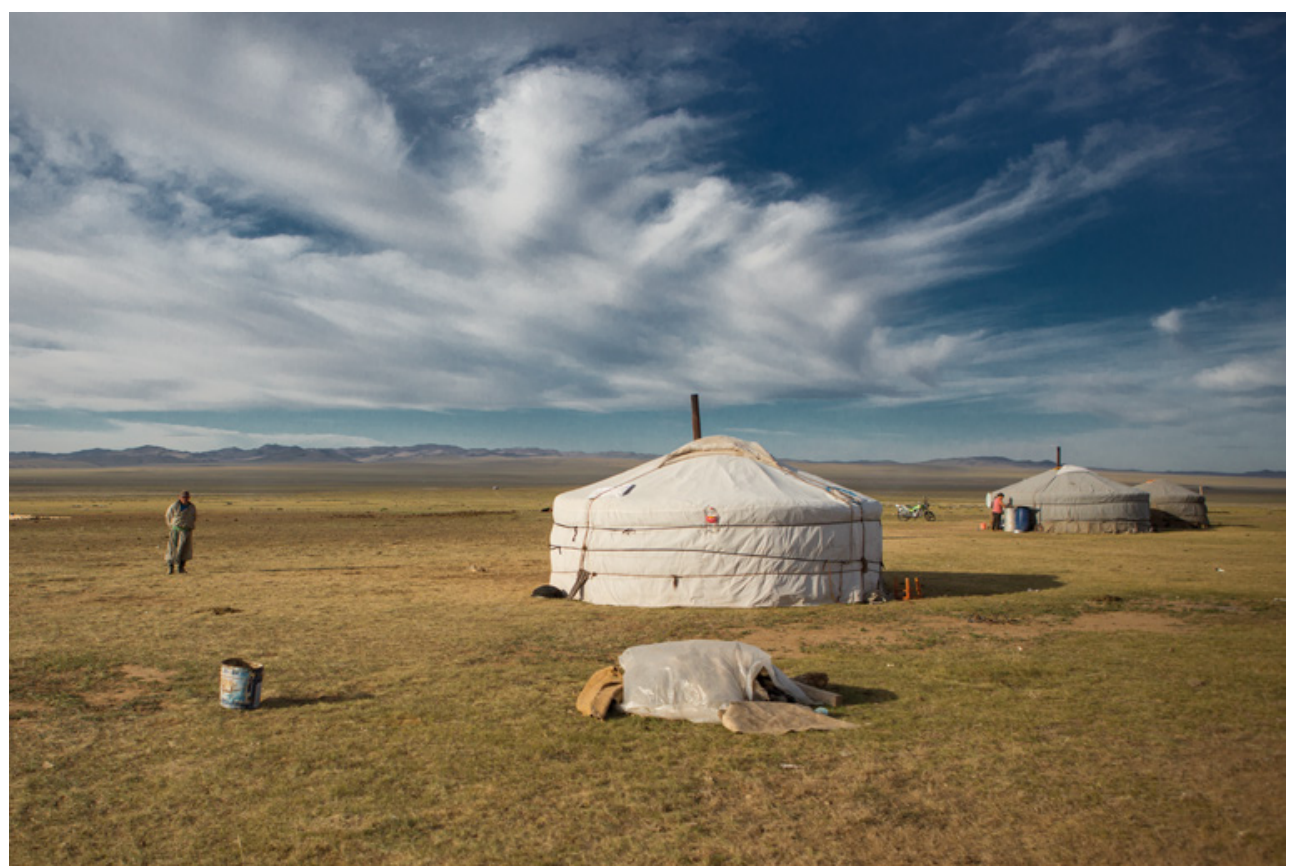

рното 11 Mongolian landscape

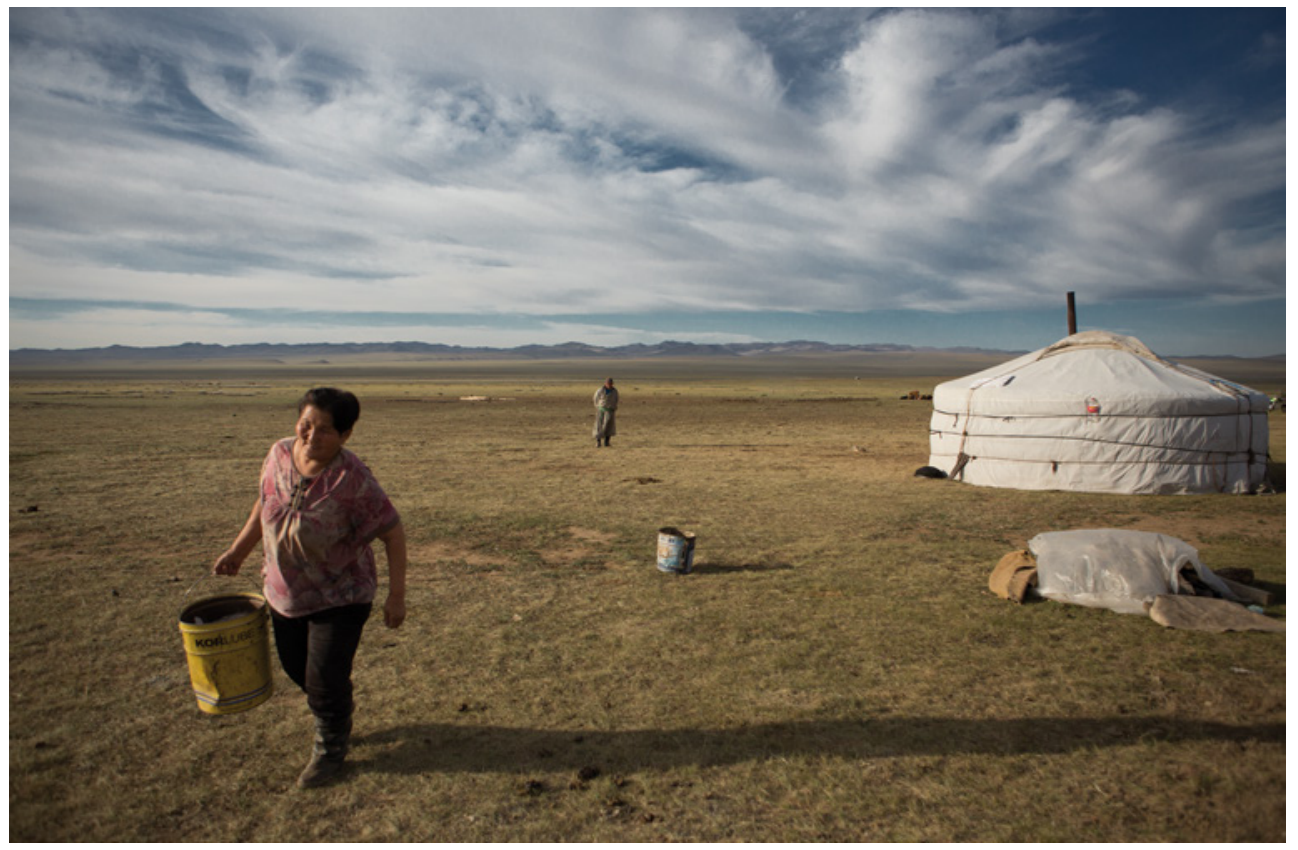

рното 12 Mongolian landscape

Paul D. Buell, E.N. Anderson, Montserrat de Pablo Moya, and Moldir 0skenbay - 9789004432109 Downloaded from Brill.come4/26/2023 12:51:29PM 


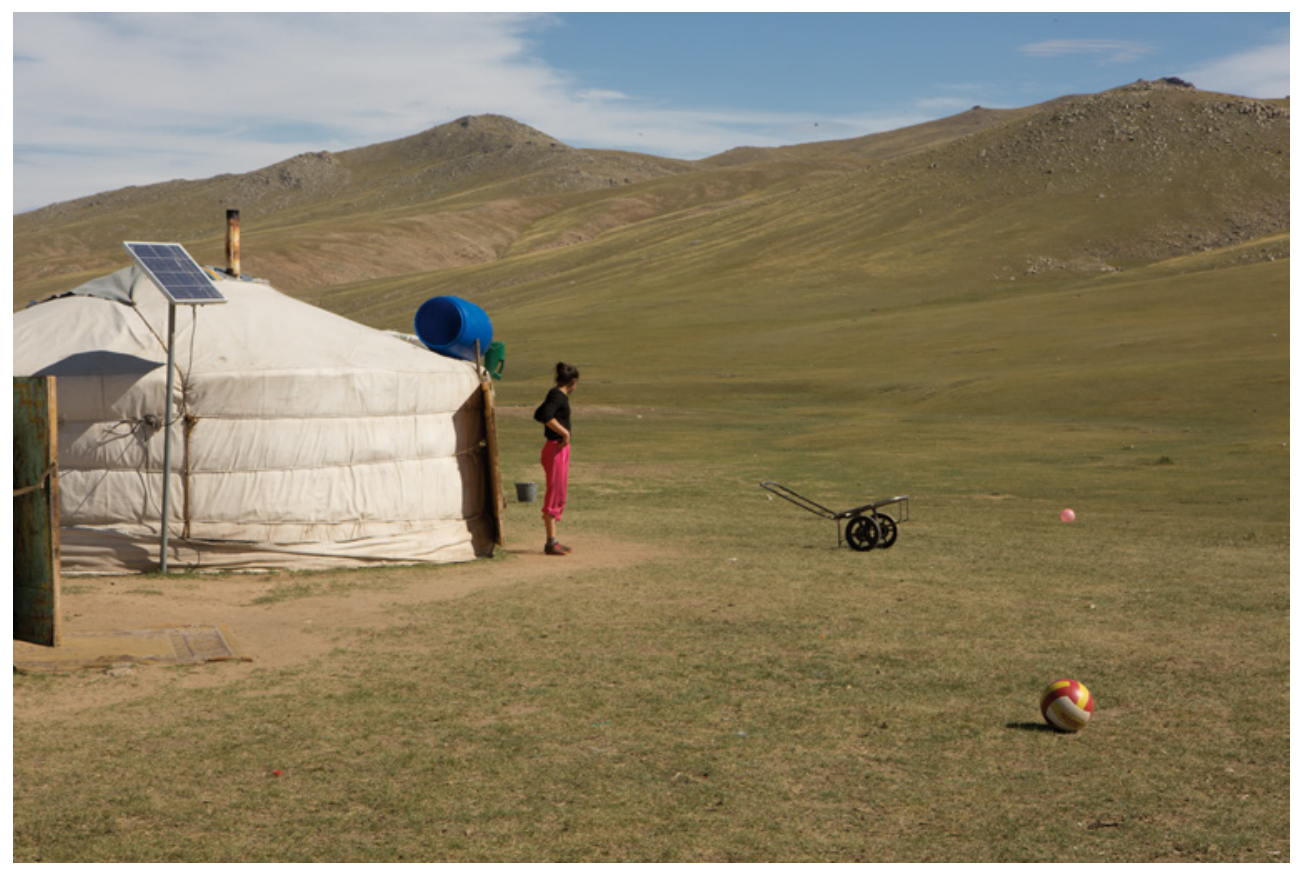

Рното 13 Mongolian landscape

strip of river hundreds of kilometers, surrounded by vast, level desert plains. The more reliable flows of the larger Amu Darya (also draining into the Aral Sea, and largely in Uzbekistan) and the more controllable Tarim in Xinjiang are more neatly checker-boarded with fields.

Such an environment was not conducive to building up great wealth or resisting conquest. Imagine the difficulty of ruling the Syr Darya and Amu Darya drainages. At stake were extremely long, extremely narrow, meandering ribbons of cultivated land, broken up by mountains and salt flats. Most of their courses were wide open to nomad raiders. Only the mountain-protected, and reliably fertile valleys of the headwaters could sustain cities and dynasties. Similar constraints applied to the shorter rivers of Turkmenistan, Afghanistan, and elsewhere. In these countries the deltas of the rivers, where they end in internal drainage basins, were the best land, supporting cities like Herat in Afghanistan. The Helmand sinks into the sand shortly past Herat, but reappears again as a large river in Iran - a rare trick even for a Central Asian stream. Often, desert rivers unite at the point where they exit the mountains, and then split up again into countless usually-dry channels, ending in internal dry lakes or salt flats. The uniting point then becomes the logical place for a city, and this is where cities like Isfahan (in Iran), Merv (located in what is now Turkmenistan), and Qaraqorum (in Mongolia) are located. 
Unfortunately, the lower delta areas of the greater rivers have often been too saline and unreliably watered to be of great use. The rivers could suddenly fail, or change course and strike out into the desert. Human mismanagement can make this far worse. ${ }^{36}$ Today is not the first time the Aral Sea has almost dried up. Northern Kazakhstan and Mongolia, both cold and dry, have few sites that can support any cities at all. The capital of Ögödei-qan (r. 1229-1241), planned by Cinggis-qan, Qaraqorum, was originally a "place where the commoners met on the pastures to feast;" ${ }^{37}$ it took advantage of a small fertile valley surrounded by almost uninhabitable mountains and dry steppes.

Agricultural societies in the region were therefore organized on the oasis level, with the biggest village or city serving as center and regional capital. The soils of desert oases are famously fertile-consider the Nile-and the nearpermanent sunshine makes them ideal for photosynthesis. Since it is often easy to bring water to sunny places but impossible (under normal circumstances) to bring sunshine from afar to rainy places, irrigated desert-valley agriculture has been a mainstay of wealth in many great civilizations.

The Eurasian heartland perfected many advances in irrigation, including backward-arch dams, complex canal systems and shifting of settlements to follow changing river channels. One striking feature of Central Asian irrigation is the sardāba, a deep cistern to trap rain and snow, which was protected by a domed cover to prevent wind from blowing the snow away or evaporating the moisture. ${ }^{38}$ It could probably trap dew also. Stone mulch for trapping dew and saving groundwater, as well as harrowing to break up capillary action and save groundwater, were well known in northwest China by early Han 漢 times. ${ }^{39}$

Another vitally important invention is the qanat, in the eastern part of the region called karez. A qanat is a water tunnel, dug back into the large outwash fans that form where mountain streams debouch into valleys. Released from canyons, the streams spread out and drop their load of gravel, sand, and soil. They sink into these porous fans. The water is still there, far below the surface; it is lost to the upper world. Tunnels driven back deep into the fan can tap the underground flow. A series of deep shafts—essentially, wells—is driven, until one strikes water or water begins to accumulate in the bore of the shafts. Then a tunnel is built from that point down to the valley, with shafts every few dozen meters to remove the dirt. ${ }^{40}$

\footnotetext{
36 Brite, "The Archaeology of the Aral Sea Crisis," 14.

37 On the structure of Mongolian society over time see Gongor (1970, 1978), Khalkh Tovchoon, 2 vols.

38 Pugachenkova, Dani, Liu, and Alexandre (2003), "Architecture," 477-526 (491).

39 Anderson (1988), The Food of China.

40 See good description and diagram in Dupree (1980), Afghanistan, 49-51.
} 


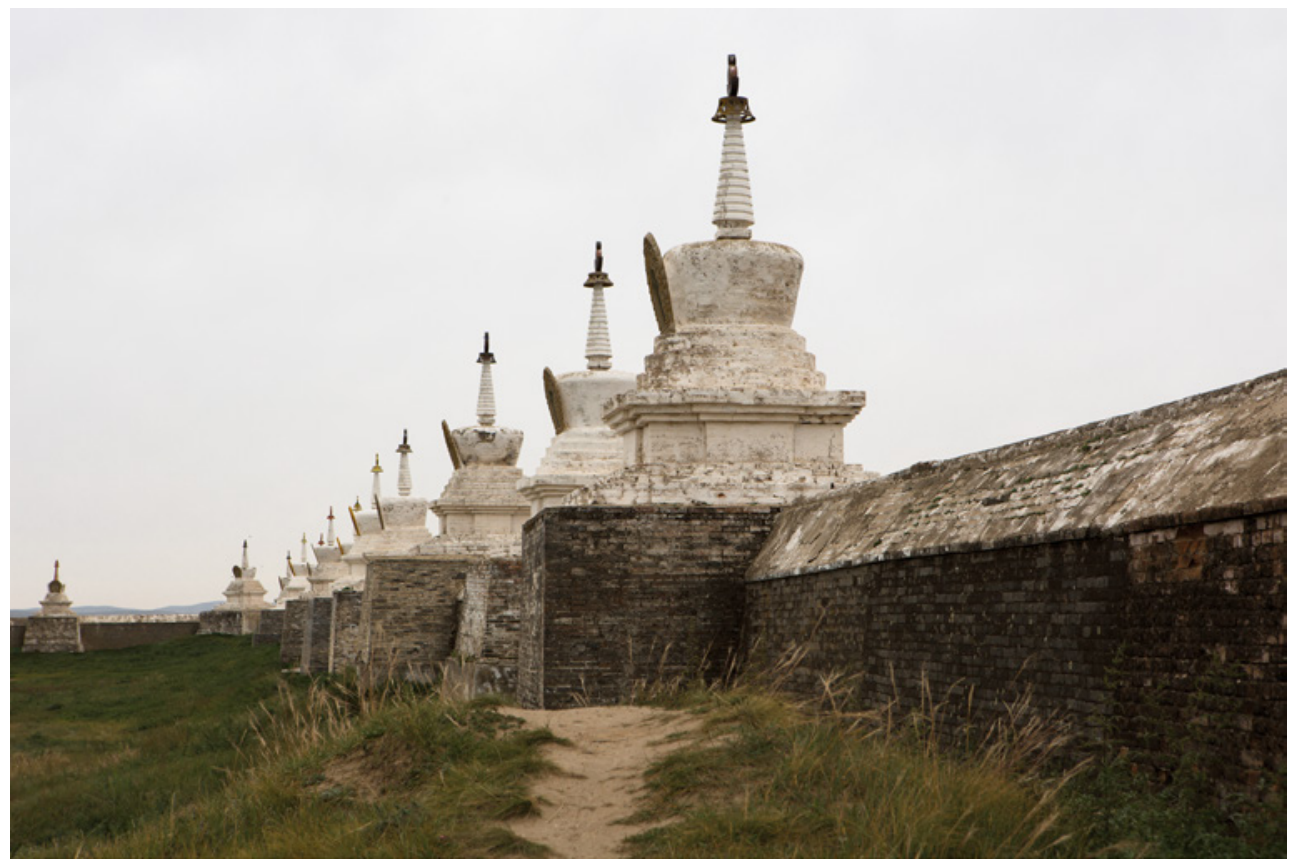

Рното 14 Qaraqorum today

This technology was apparently developed in Iran, perhaps 2000 years ago or more. It spread into the heartland, which became its major stronghold. It allowed cultivation of tens of thousands of acres that would otherwise have been waterless. It is now rare, but satellite images, especially in remote parts of western Afghanistan and in the Turpan basin, still show the characteristic lines of holes, ringed by dirt, in desert outwash fans. Beween Qandahar and Lashkar Ga in Afghanistan, some of the villages are even named "(Such-and-such) Karez." The karez system that waters the Turpan oasis in Xinjiang is particularly impressive, tapping aquifers in the Flaming Mountains with 1784 channels totaling $5^{272} \mathrm{~km}$. Some 614 are operating today. ${ }^{41}$

In the other direction, the technology spread to North Africa and thence to Spain with the Moors. When Moorish converts to Christianity were sent to Mexico in the 16th century, they brought their technology to the Tehuacan Valley. Tehuacan Valley migrants brought the idea of "water tunnels" to San Bernardino, California, in the 19th century (information to Anderson from oldtimers half a century ago). So southern California is linked to ancient Iran in a most surprising way.

41 Baumer (2014), The History of Central Asia. Vol. 2: The Age of the Silk, 170. 
One problem in the modern heartland is urban sprawl onto the extremely limited irrigated land. Even in medieval times, Turkistan had large cities, and the idea of expanding them desertward was made problematic by water supply difficulties. Villages are, at least in Afghanistan, sited off the farmland. ${ }^{42}$ This fact is confirmed by satellite photos and our personal observations. Villages in ex-USSR areas, and in western China, by contrast, are usually sited on farmland. Despite this, since every household has its garden and orchard, the irrigated land is still in use. In Mongolia, the issue did not arise until recently because of the dispersed, nomadic settlement pattern. Now Ulaanbaatar has a serious case of sprawl. Cities pave over everything. Today, although there is no excuse for urbanizing the limited farmland, it goes on. In imperial times, the Chinese and Koreans worked hard to keep cities from claiming any more farmland than they had to. This idea has now been abandoned because of modern "rationality." Tashkent, for instance, is now a city of about two million, and has devoured a large percentage of the arable land in north Uzbekistan.

Other areas of fertile soil are the far northwest and northeast corners of the heartland, where thousands of years of grass growth led to the development of incredibly fertile soils. Grass, unlike trees, is largely underground; the roots, especially of perennial steppe grasses, outweigh the leaves. Also, grass does not produce the acid litter that trees do; it produces a neutral to slightly basic litter that improves the soil over time. Grass retards erosion and holds the soil. In a grassland or dense brushland, every incipient gully is choked by vegetation taking advantage of the extra moisture. This creates negative feedback that checks gullying - the erosion that causes rapid formation of deep gorges in the soil.

Today, people have learned the hard way that stripping off the grass cover immediately destroys this feedback. This leads to catastrophic gullying. Thousands of years of accumulated soil can be washed away in one rainy season. This is happening now in Inner Mongolia, where there is the added complication of huge open-pit mines, and it has happened in Russia and Kazakhstan with cultivation of the grass steppes. The "virgin lands" campaign to cultivate the Kazakh steppes ended in abandonment of about half the land after erosion set in.

Heartland grasslands are dry and cold. They have thus always been marginal for agriculture. The frontier of farming would expand in moist, warm decades and contract in cold, dry ones, as famously pointed out by Raphael Pumpelly. His theory was later transmitted by Ellsworth Huntington, ${ }^{43}$ and then followed

42 Dupree, Afghanistan, 134.

43 Huntington (1907), The Pulse of Asia. 
by Owen Lattimore, ${ }^{44}$ and by almost everyone since. Less often noted is the long-term damage wrought by farming expansions. Abandoned farms eroded fast. Farmers depleted game, by hunting but more often by destroying habitat, and thus closed off another mode of subsistence. The dynamics of nomadism and its interfacing with "the sown" have been explored at length by Thomas Barfield. ${ }^{45}$

Central Asia displays every possible type of integration of stockrearing and farming, from stalled livestock on farms on the northern and southern fringes to full nomadism and occasional trade for farmed goods in the Mongolian and Kazakh steppes.

While individuals and families may manage independently for a while, as they certainly have in the past, nomad societies as a whole cannot. ${ }^{46}$ They depend on the settled world for such things as metal tools, some clothing items (though they make much from wool), and minor commodities such as tobacco. For at least part of the year, they depend on grain (especially wheat flour). In the past, grain could be provided by captive farmers moved to oases in the steppe. Nomads could also grow millet themselves, especially during warmer, wetter periods such as the 12 th and $13^{\text {th }}$ centuries. Millet matures in as little as two months, allowing people to grow it at summer campsites. Nomads may also depend on stubble in agricultural fields for winter fodder.

Unlike many East African herders, Central Asian herders cannot live entirely on the dairy products from their herds. Pastures are too poor or limited in size to allow high levels of milk per animal, and thus a surplus of dairy products. So wool, skins, products of the hunt, and meat are traded with settled folk.

Around the riverine oases, herders use flood-prone river bottoms, grassy margins, hills, and areas of steppe too dry for farming. They are thus in daily contact with farmers, and trade frequently. They grow all the species and many varieties of stock. They are not nomadic, or not for long distances.

Often found with them, at least in winter, are transhumants: semi-nomads who move from lowlands in winter to mountain pastures in summer, thus

\footnotetext{
44 Lattimore, Owen (1940), Inner Asian Frontiers of China.

45 Barfield (1981), The Central Asian Arabs of Afghanistan; Barfield (1989), The Perilous Frontier; Barfield (1993), The Nomadic Alternative; Barfield, "Centralization/Decentralization in the Dynamics of Afghan History," Cliodynamics 3:1 (2012), 94-104.

46 Honeychurch and Amartuvshin, "States on Horseback: The Rise of Inner Asian Confederations and Empires," in Stark (2006), Archaeology of Asia, 255-278.
} 
having two homes, and taking anything from a few days to several months to make the journey. Transhumance is a worldwide phenomenon, very common among herders from Mongolia to modern America.

At the other end of the scale are Mongolian mountain herders who have permanent homes around springs and streams, but were extremely isolated until recently. Also remote are steppe nomads of the Mongolian gobi and the Kazakh and Turkmen steppes; they might go for months without seeing settled people, coming to markets to trade, make political deals, and find spouses for their young adults. Usually sleepy market towns would be suddenly jammed and packed with humans and livestock as whole tribes met to deal. Every imaginable variation on the above basic types is found somewhere. The diversity of adjustments allows maximally efficient use of grazing and browsing resources while allowing at least occasional access to settled oases and trade centers for agricultural and urban products. There is, in short, a symbiosis of settled farmers and merchants with several different types of stockraisers, from settled mixed-crop farmers with barns (or lower house-floors dedicated to livestock) to full steppe nomads.

\section{$7 \quad$ Nomads}

Although nomads have been a minority of the population of Central Asia, at least until recently they were the occupants of most of the land and have been important in maintaining contacts and in large movements of culture, goods and things. Nomads generally conserve the grasslands carefully. Not doing so would be suicidal, and shows nomadic understanding of environmental balances. By contrast, modern policy makers love to claim that nomads are ignorant fools. Three thousand years of accumulated experience counts for nothing. These policy makers do everything they can to change traditional management, with invariably catastrophic results. The detailed studies by Dee Mack Williams ${ }^{47}$ should be essential reading for all students of grassland management. ${ }^{48}$

47 Williams, "The Barbed Walls of China: A Contemporary Grassland Drama," Journal of Asian Studies 55 (1995): 665-691;Williams, "Grassland Enclosure: Catalyst of Land Degradation in Inner Mongolia," Human Organization 55 (1996), 307-313; Williams, "Representations of 'Nature on the Mongolian Steppe: An Investigation of Scientific Knowledge Construction," American Anthropologist 102 (2000), 503-519; Williams (2002), Beyond Great Walls.

48 Murphy, "Booms and Busts: Asset Dynamics, Disaster, and the Politics of Wealth in Rural Mongolia," Economic Anthropology 1 (2014), 104-123. 
Mongol nomads are so careful that they do not allow heavy grazing near water holes, though this is changing. ${ }^{49}$ We have observed both traditional use and unfortunate modern changes in Mongolia. Good management is also reported for Afghanistan by Louis Dupree and others, and observed by Anderson in the 1970s. Dupree notes the nomads' pride in their lifestyles, and the sorry history of forced sedenterization in Iran and in the former USSR. In both areas, particularly in the USSR, the cost was horrible bloodshed and economic havoc. Dupree concludes, with some exaggeration, that "any nomad desiring to settle down would be considered psychopathic by his peers." 50

Traditional collective management has worked well. Ironically, in light of the well-known "tragedy of the commons" concept (the idea that people will overuse common-pool resources from lack of a real stake in them), ${ }^{51}$ privatization and the changes associated with privatization, de-collectivization, for example, are the real problem. ${ }^{52}$ Usually, overgrazing by nomads occurs only when they are prevented from moving, or are trapped by impoverishment. This may be due to a population increase beyond a constrained environment's carrying capacity. It is also possibly associated with a semi-urbanization of herding communities for one reason or the other. How this plays out we see clearly in the vast urban fringes of Ulaanbaatar, where a substantial part of Mongolia's population now lives, still in yurts. These yurt-dwellers usually have animals too, sometimes whole herds, making the constrained areas even more hard-used. To keep warm, the yurt-dwellers burn coal, mostly in open stoves, making Ulaanbaatar's air pollution problem, already one of the worst in the world, still more difficult. Only a few months of the year have reasonably good air now.

Ulaanbaatar, a city of 1.4 million, now grows continuously, and is unable to cope with the growth; meanwhile, too much housing in rural areas is derelict and decaying, thanks to changes since the communist era. In any case, whether the range is fenced, or built upon, pastures are destroyed. When there is fencing, the result is overgrazing of the fenced enclosures, a loss of wildlife (they are fenced out of necessary feeding grounds), and a catastrophic decline of overexploited range resource. The effects of a buildup were painfully obvious to us in and around the yurt districts of Ulaanbaatar. It is now expanding

49 Sternberg, "Piospheres and Pastoralists:Vegetation and Degradation in Steppe Grasslands," Human Ecology 40 (2012), 811-820.

50 Dupree, Afghanistan, p 168.

$51 \quad$ Hardin, "The Tragedy of the Commons," Science 162 (1968), 1243-1248.

52 Wenjun and Huntsinger, "China's Grassland Contract Policy and Its Impacts on Herder Ability to Benefit in Inner Mongolia: Tragic Feedbacks," Ecology and Society 16:2 (2011), article 1. 
everywhere into very sensitive areas, as far as the eye can see. The process is still more advanced in Inner Mongolia, with massive recent Han 漢 Chinese settlement.

One problem with nomadism is that nomad herders are unkind to underbrush. Underbrush interferes with grass, makes good firewood, and is grazed by camels, goats, and cattle. Trees and grass may flourish, but the variety of brush communities are still at risk. The thin stands of trees along Asian rivers, and the savanna-like landscapes of Afghanistan foothills, are due to elimination of undergrowth rather than to natural spacing. Valuable desert plants like saksaul and wild almond are diminishing.

On the whole, nomads are extremely careful of their lands. Modernizing agents are not, and usually have little respect for stockraisers. The contempt of town bureaucrats for grazers is not even confined to scorn for traditional nomads. It extends to modern Asian stockraisers. In fact, it even extends to wellto-do, college-educated ranchers in the United States, when an urban bureaucrat with no experience on rangeland patronizingly tells a third-generation rancher how to manage his grass. ${ }^{53}$ Admittedly, American ranchers are often much worse managers than Mongol herders. This occurs, however, only when they have cynically written the land off because they plan to sell out or otherwise change course. Serious ranchers know how to manage range. Many a bureaucratic plan has had the same effect in California as in Mongolia. So, one does not have to be an "ignorant nomad" to fall afoul of bad plans. James C. Scott's sour meditations on bureaucracy are relevant. ${ }^{54}$ The heartland, between communism, extremist religion, and world-traveling economic advisors, is suffering from crises caused by bureaucratic insolence, including disregarding local knowledge and practice. This is even visible from space, if one compares satellite photos of Chinese Inner Mongolia and independent Mongolia. The role of Communist party policies in the former makes its frontier with independent Mongolia conspicuous by the desertification on the Chinese side.

The nomads are intensive stockraisers, specializing in sheep, also keeping goats, camels of both species, horses, cattle, donkeys, and yaks, as climate and altitude permit. Sheep, goats, and dromedaries dominate the hot zones; sheep, goats, and horses the cooler and better-watered ones; sheep, horses, and yaks flourish in the highest and most remote parts of eastern Central Asia. Bactrian camels are common in the hotter, drier parts of the East, especially in Xinjiang

53 Kimberly Hedrick (2007), "Our Way of Life: Identity, Landscape, and Conflict," and personal communications to Eugene N. Anderson, 2000-2010.

54 Scott (1998), Seeing like a State. 
and southern Mongolia. Donkeys and cattle are rarer everywhere, being creatures of better-favored climes. In the popular mind, yaks are identified with Tibet. They also flourish in the mountains of northern Mongolia and elsewhere, raised as a herd animal in some areas.

The livestock are ecologically diversified. The horse and donkey do not have the fore-stomachs (n.b., fore-stomachs are not four stomachs) that allow sheep and cattle to use the full range of vegetation. Horses (but not donkeys) require high-quality food: good protein-rich species of grass, such as oats, or protein-rich clovers. The Iranians early domesticated alfalfa, a clover that is an almost perfect horse feed. (It is a bit too rich; the horses must eat some grass hay to keep from overenthusiastic digesting resulting in colic.) Horses spend much less time and effort digesting, compared to cattle, and donkeys can eat relatively coarse food that would clog the fore-stomachs of cattle. Conversely, cattle (including yaks) and goats can eat anything with carbohydrates in it. They thrive perfectly happily on wood, as long as it is either browsable on a bush or finely ground in the form of sawdust. They eat sugar cane, processing waste, chicken manure, cotton stalks - almost anything. Goats are famous for their ability to thrive on what the Greeks so aptly called tragacanth- "goat thorn" - vegetation. Sheep are much choosier, but they too have fore-stomachs and can eat forage that would not sustain a horse.

Each animal has its place: horses on the grass steppe, cattle in low warm valleys, sheep anywhere that has grass, goats anywhere that has brush, donkeys in warm areas with rough forage, yaks in high mountains, and camels in the desert. A herder will always have a mix, tailored to the climate and vegetation of his or her area of nomadizing.

Normally, this will involve migration. The stockraisers usually winter in low valleys; today grazing occurs whenever possible in winter-fallowed fields. They then migrate with their flocks to higher country, if possible to lush mountain pastures for the summer. This pattern of transhumance is common among stockraisers everywhere that mountain meadows exist. If no mountains are nearby, herders must take their chances on the vast open steppes, finding local water sources and grassy vales. This means they must know the routes perfectly, to be able to calculate how much water is available for themselves and for their animals along a given route. ${ }^{55}$

Nomads do not usually own lands outright; they have customary grounds and routes, and tribal territories that are recognized fluctuating with weather and with rivalries. Fighting over rights to graze a particular area used to be

55 Classic studies of nomads include Louis M. J. Schram (1954-1961), The Monguors of the Kansu-Tibetan Frontier, American Philosophical Society, Transactions, 44:1-51:3. 


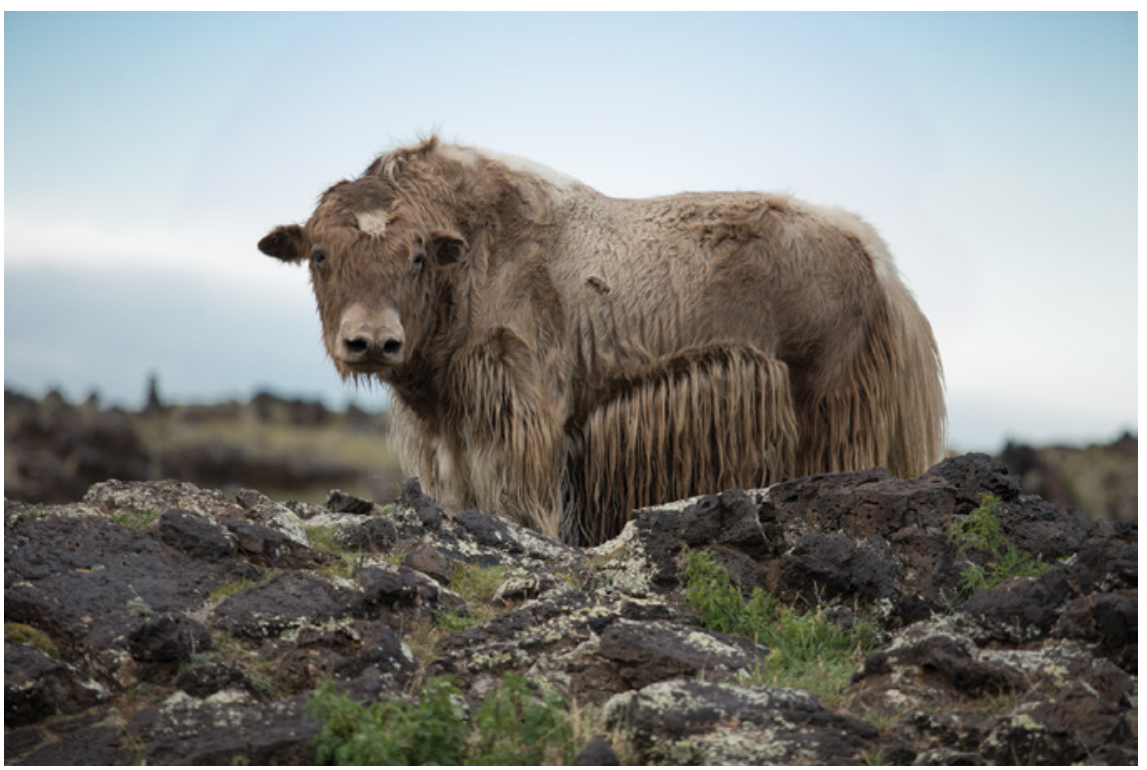

Рното 15 Hybrid Yak

frequent. Settling such disputes was a major reason for the existence of higherlevel authority among the early Mongols.

Black tents in the south, reindeer-skin tipis in far north Mongolia, and stone houses in the mountains are local housing types, but the great contribution of Central Asian nomads to the world is the felt-covered wood-framed house known as yurt in Turkic languages and ger in Mongolian. The skeleton is a collapsible fabric of split poles. A yurt can be knocked down or set up in a very few hours, yet it is a stable, convenient, extremely comfortable home, warm in the harshest winter, cool in summer. Its popularity in the modern United States is adequate testimony to its success.

Nomads also hunt, as noted above, and have strikingly good traditional conservation rules that keep their game numerous - a wise measure often lost on farming settlers, especially pioneering ones. ${ }^{56}$ The Mongols teach respect (shuteekh or khundlekh in Mongolian) for nature, and Mongols today still refrain from overfishing, overhunting, and overcollecting. Even mountains, water, and rocks are respected and guarded usually by an ovoo, focusing spiritual

56 Anderson (2014), Food and Environment in Early and Medieval China; also Arseniev (1996), Dersu the Trapper (Dersu Uzala). The latter is a romanticized account but true to Tungus culture in this regard. 
power when people are not available. We talked to one young Mongol woman of nomad background who liked pretty rocks but she did not collect them, because it is disrespectful to rocks to move them around for no good reason. ${ }^{57}$ In early times in Mongolia the land and waters belonged to special gods, ejen, "lords."

A major problem for understanding the Eurasian heartland is the myth of the "barbarian" nomad, stemming from the ancient Greeks and especially the later Byzantine Greeks. It was reinforced by similar stereotypes among Chinese. ${ }^{58}$ Nomads are not uncouth, savage beings who wander aimlessly over the vast steppe. In fact, the extreme opposite is true: they must know every inch of their landscape. Water and forage sources adequate for a herd are so limited that anyone not knowing the terrain will certainly die.

It is chilling if not terrifying enough to ride in a modern four-wheel-drive vehicle with a GPS unit on the back roads (and nearly all roads are back roads except in a few favored areas) of the Mongolian Gobi. There are few true roads. There are only wheel ruts, sometimes quite deep ones, on the desert pavement. Sometimes these are nearly big enough to swallow a vehicle. In rainy times, a moderate drive means much fording of streams. These back roads constantly branch, with forks going off in all directions - almost all of them petering out in the midst of desolation, or in some sand flat, or gully where the vehicle will get stuck. Getting lost or stuck can mean death. Fuel soon runs out. The nearest cellphone service is hundreds of miles away, and in summer temperatures up to $40 \mathrm{C}$ guarantee that life does not last long without water. Problems are just as severe, or more so, in winter. Obviously, the dangers were much greater 100 or 1000 years ago, and the need for exquisitely thorough and accurate knowledge correspondingly greater. So nomads followed well-known trails. They moved from well-known wintering grounds to well-known summering territories. They had to know many alternatives, since the grass was apt to fail in one or another area in any given year.

On the other hand, if they could live by raiding, or were assured of trade opportunities, there was once little or nothing to stop them from riding off across the vast landscape (so long as they had a guide to lead them to water) and swooping down on settled communities. Cultural and tribal groups spread rapidly. The Rouran 柔然 of China's western frontier, for example, apparently departed en masse when the Tarim River shrank dramatically during a dry

$57 \quad$ Eugene N. Anderson, field notes, 2013.

58 Barfield, The Perilous Frontier; Barfield, The Nomadic Alternative. 


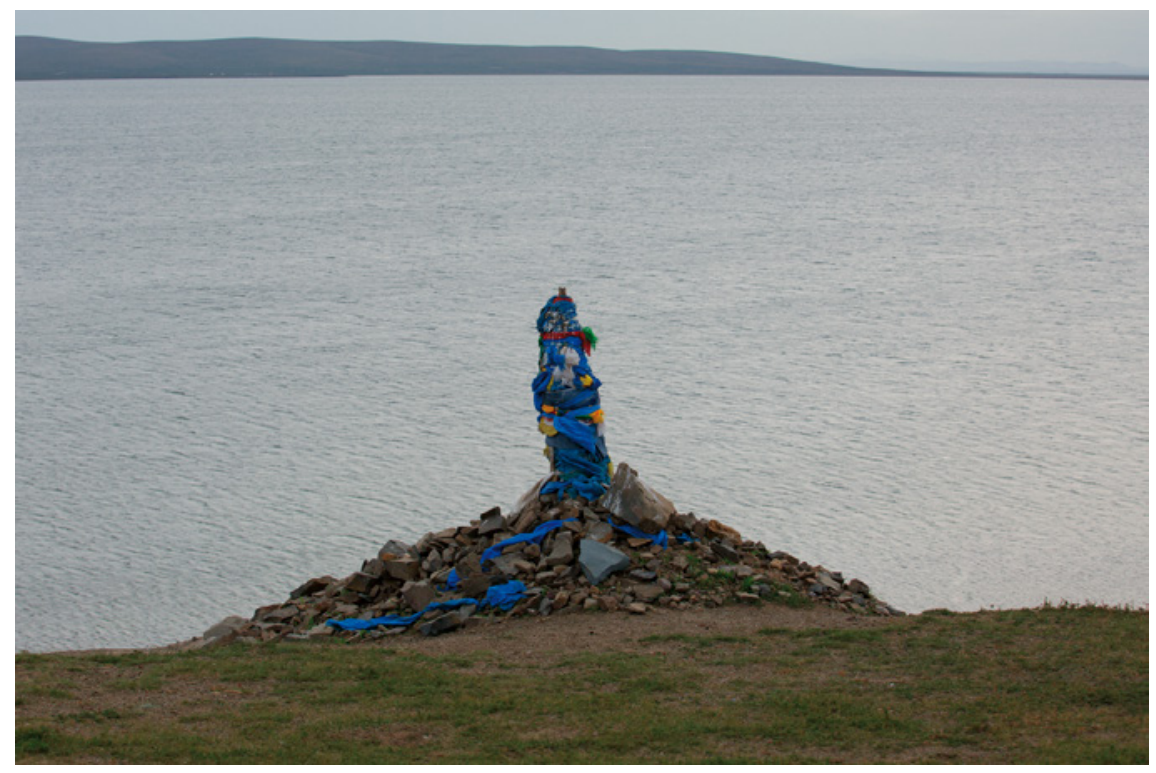

Рното 16 An Ovoo

period, ${ }^{59}$ appearing (at least in part) as the Avars (Abars) in Eastern Europe. ${ }^{60}$ There they gave the Byzantine Emperor a run for his money, establishing relationships typical of those between nomadic and sedentary people. This is reflected among other things in a wonderful story in the histories of Byzantine historian Theophylactos (Historiai, I, 3-5) where the khan of the Avars demanded that the Byzantine emperor send him a tax-in-kind on all his animals. This the emperor did. He also did the khan one better by sending an elephant from the imperial zoo. The khan had no idea what to do with his elephant and had to return it. This story may have little to do with food, it still stands as one of the clearest examples of an age-old lack of understanding between the desert and the sown.

Central Asian nomads, whether they have access to elephants or not, are not entirely self-sufficient; they cannot live from the products of their herds alone. Today, a solar panel, a radio, if possible a TV, a GPS system, even a motorcycle are increasingly seen as necessities. Solar panels are easily powered in sunny Central Asia. Authors Anderson, de Pablo and Buell saw several installed as the

59 Fontana, Sun, Huang, and Xiang, "The Impact of Climate Change and Human Activity on the Ecological Status of Bosten Lake, NW China, Revealed by a Diatom Record of the Last 2000 Years," The Holocene 29 (2019), 1871-1884.

60 Golden (2011), Studies on the Peoples and Cultures of the Eurasian Steppes. 
sole source of electrical power for nomads living in yurts far from Ulaanbaatar in Mongolia. Except for the initial investment in the panel, and its mounting, such systems provide a lot of power cheaply. De Pablo and Buell did not see any TVs, but GPS locators were certainly in use, radios, and yurts even had electric lights. Anderson has found solar cells powering TVs in remote parts of the steppe where outsiders were almost unknown.

Although the overwhelmingly dominant type of nomadism is sheep management on horseback, with or without subsidiary animals, many different types of nomadism exist in the heartland. In addition to variants on the sheepgoat-horse theme, there are reindeer herders in the extreme north and specialized camel herders in the southernmost deserts. Sevyan Vainshein ${ }^{61}$ provided a classic account of the development of reindeer herding in the Altai from earlier forms of herding.

Throughout history, nomads have often settled down, and settled groups have become nomadic. Often this is a function of conquest; often it follows climate change that makes one, or the other mode of livelihood less attractive. Partial nomad groups exist: both groups that move from settled villages for part of the year, and groups that are divided into some who nomadize, and some who do not. In short, we do not find the wholly nomadic, self-sufficient world that is still a living memory in Somalia and Kenya. Therefore, we do not find the sharp differences in ethnicity between herders and farmers that characterize some parts of Kenya.

Nomads were usually organized by kinship, with descent traced primarily through the father. Women were also important, so the maternal lines were not ignored. Tribal or larger horde (from Middle Mongol hordo, "palace tent") groups, where they existed, usually only in conquest situations, could be based on extensions of kin too, often reaching back to mythical paternal ancestors. Commonly, if not always, these were the symbols of power: wolves or other fierce, dominant animals. According to ancient tradition, the Mongol people descend from the union of a gray wolf and a fallow doe-symbolically, indomitable social power mated to gentle beauty. The Turks also descended, mythically, from a wolf.

More recent ancestors are more human: Uzbekistan takes its name from the Uzbek (or Özbek) Turks, a group put together by an Uzbek qan in the 14th Century. Like all good steppe leaders, he developed an ever-expanding circle of kin by attracting more and more distant relatives, and thus a descent group that still survives emerged. Over the years, it attracted more and more distantly related or totally unrelated individuals, until it now dominates a whole nation.

$61 \quad$ Vainstein (1980), Nomads of South Siberia. 
Descent is not just an imaginary commodity. A very large percentage of the current inhabitants of the Eurasian heartland, and beyond, trace descent from Cinggis-qan, and genetics show that many do indeed have a common male ancestor at about the right time. Nonetheless, real kinship was never a limit; people could form huge confederacies based on all sorts of fictive or purely imaginary kinship lines. Failing even that, they could, and did, form adoptive, sworn-brother, and marriage links. Pledging one's son to one's ally's daughter was universal. In the Secret History, such a practice is formalized as a duty of daughters and other female relatives as yeke töre, "imperial system." ${ }^{2}$ These kinship relations are critical to maintaining the social support necessary to subsistence and survival, and thus a part of the wider food system.

The nomadic lifestyle does not date back to "time immemorial." It developed between three and five thousand years ago, as farming and metal came to the region. Critical was the domestication of the horse for eating and milking around 3000 BCE. Riding came much later, but was an equally critical innovation. Nomadism has changed rather dynamically over the millennia.

The "nomad" empires of the steppes were not literally that. The idea of wild horsemen charging down on the settled farmlands is romantic. Both the Chinese and the Byzantines loved to portray the "barbarians" this way. In fact, most of the empires had to have substantial cultivated areas within their limits. Otherwise they simply could not feed or supply their capitals and troops. Nomads might create huge forces of raiders but could not maintain a state simply by raiding. Any sensible conqueror, from the Shanyu 單於 of the Xiongnu 匈奴, to Cinggis-qan, and on down to modern times, would conquer a large area of settled farmland early in the game, and use it as a supply source. This had huge long-term effects on the food economies of Central Asia. For one thing, it led to cultivation of vast areas that were agriculturally marginal, but politically central--such as what is now northwest China, when the Xiongnu Empire conquered it.

Similarly, the great agrarian empires based in the oases usually incorporated nomadic and partially nomadic groups. They also had to work with, and fend off, the nomadic confederacies. Often, the nomads won, settled down in the oases, and in turn had to fend off new nomadic groupings.

A final note on the Eurasian heartland nomadic world is conflict. Consistently, throughout space and time, it has been dedicated to war. Every group is a potential or actual enemy to every other group. Kinship groups snowball into vast hordes. But these hordes can just as easily break up again. Loyalties shift

$62 \quad$ Buell and Kolbas (2016), "The Ethos of Sate and Society in the Early Mongol Empire: Chingiz Khan to Güyük," 43-64. 
readily. Yet this no-holds-barred world was also a world of great freedom and power for both men and women. Queens were important and often ruled whole states. Women had independence and authority in the family. One can still see this in Mongolia, where neither Islam nor Chinese culture has been able to introduce more restrictive norms (as they have elsewhere).

Not only in Mongolia, but in all nomad and in many settled societies, respect for nonhumans and thus care for all creation was universal. This has been the true root of Mongolian and other Heartland environmentalism.

The Crossroads

The Eurasian heartland has always been the crossroads of Eurasia, but this has meant very different things at different times. Since it is largely dry and desolate, with much of it downright uninhabitable, it has rarely been a great center of culture and civilization. Nonetheless, Medieval developments in the Eurasian heartland in food, diet, and medicine, had effects still powerfully felt in China, and in the Western world today. Scientific writers such as al-Bīrūnī (9731048), and Avicenna (980-1037), both from the heartland, for example, transmitted or created a good fraction of the medical knowledge of their time. Much of this has come down to us.

The Eurasian heartland has always been a linking area between the Western world — the Middle East and Europe — and the Eastern world of China and the realms it influenced. This has had a somewhat unfortunate effect on our understanding, since it has often been seen merely as a link, interesting only for what it revealed about the West or the East. This has resulted in many fruitless debates about how much influence each had on the other, with little attention paid to the thousands of miles in between or the people that have lived there, often enjoying a high level of civilization.

Foodways in the Eurasian heartland have come largely from the West, but the area has witnessed its own developments. Some of these may appear forgettable to outsiders, such as fermented mares' milk, but all have had their place in nutrition. The dairy-products culture of the steppe areas is, in fact, a major tradition in foodways, and persists outside as well (as in modern Turkey, with its rich tradition of yogurts and cheeses).

Even China has borrowed from the steppe. The horse and its trappings are obviously the main borrowing, but sheep varieties, the Bactrian camel, and no doubt other steppe innovations add to the much greater list of western Eurasian inventions channeled through the steppes and along the Silk Road. Among other things, bean curd (doufu 豆腐) may be a cheese imitation. China 
had its own cheeses, we now know, from early times, and doufu - apparently invented in the Han Dynasty - may have been inspired by them, or directly by nomadic cheese making.

\section{9}

\section{Overall View of Foods}

The Eurasian heartland is unified by geography, better unified by language (mostly Iranic or Turkic), ${ }^{63}$ but thoroughly unified by food. Thanks to both geography and cultural traditions, wheat dominates as staple food. Everywhere, the wheat is made into bread, noodles, and noodle skins. The area is replete with wheat-based foods. They include the local samosa, an Arab and Iranian tradition, and the ubiquitous manty. These small filled dumplings are found all over the Eurasian heartland and as far afield as Korea (mandu). Their origin remains obscure, but the wide use of various Turkic names for them may indicate a Central Asian origin.

Other grains, millet, barley, are of minor significance. Sheep are supplemented by goats, cattle, horses, and locally yaks and camels. Meat is important everywhere, dairy products more so, with a full range: milk, dried whey, cream, yogurt, cheese, and various other products. Notable among these is the famous kumiz, fermented mares' milk. It is not to everyone's taste. Ibn Battuta was offered it by the Queen of Uzbek Khan, the ruler who gave the modern Uzbeks his name: "I tasted it and [finding] it disagreeable passed it on to one of my companions." ${ }^{44} \mathrm{He}$ was not the first or the last to react thus. The vodka made from a distilled cow's milk is better. Kumiz tastes rather like buttermilk mixed with beer. Shubat, camel kumiz, is even richer in taste. There is also a distinct sour bite and a feeling of effervescence.

Vegetables are few, including carrots, cucumbers, spinach, and eggplants. In the last couple of centuries have come the New World suite of tomatoes, potatoes, and - locally in the south and east—red peppers. Onions and garlic are universal, perhaps the major vegetables. Cut-up cucumbers and tomatoes (sometimes with dressing, usually without) are a routine accompaniment to meals. Fruits, especially grapes, melons, apricots, and apples, are common and important. Spicing and seasoning are rather simple. In addition to salt and pepper, the favorite Near Eastern spicing of cumin and coriander (seeds and leaves) is widespread. Cinnamon, cardamom, ginger, and other exotics are concentrated around the edges of the region. China's soy sauce, ginger, and

63 On Turkic food see Perry (2006), "Nomadic and Medieval Turkic Cuisines," 116-131.

64 Ibn Battuta (1958-1971), The Travels of Ibn Battuta, II, 487. 


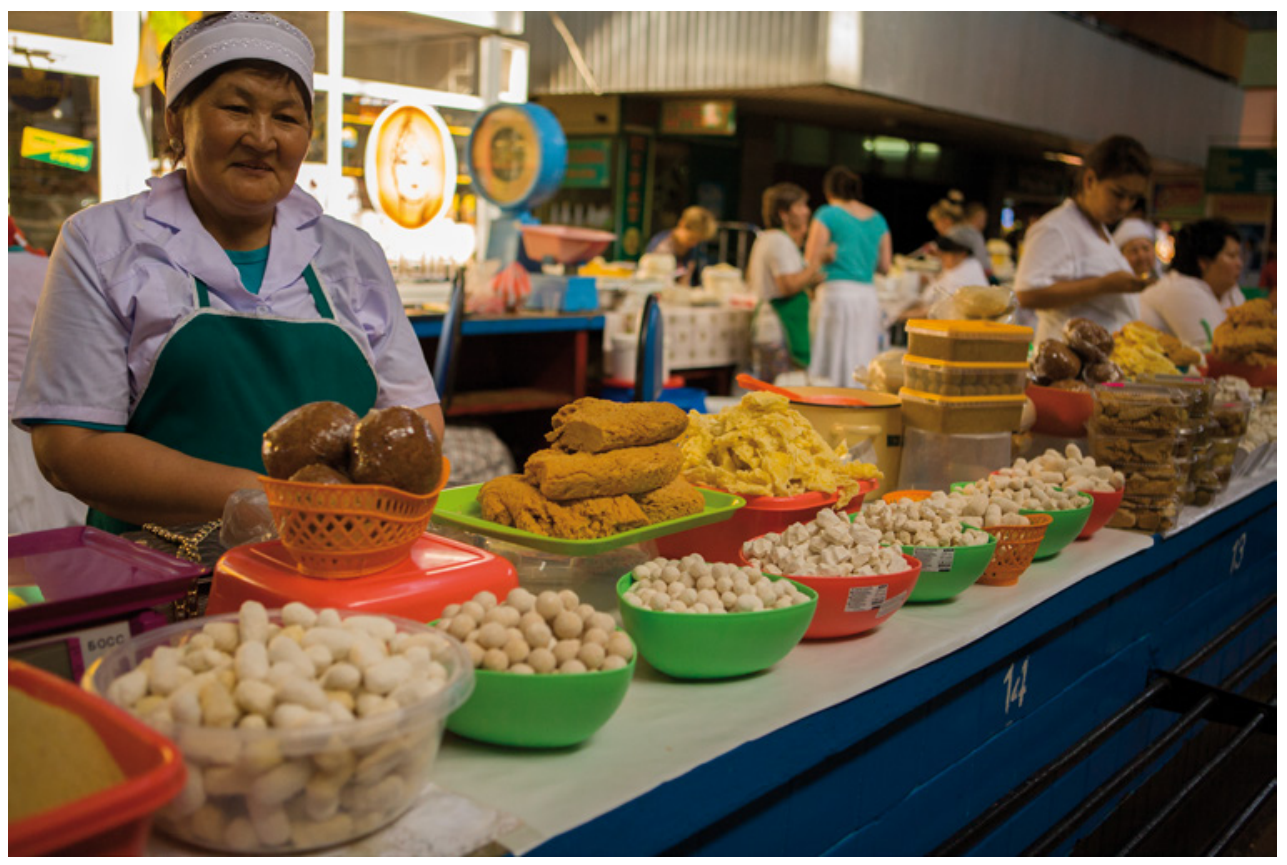

Рното 17 Almaty market

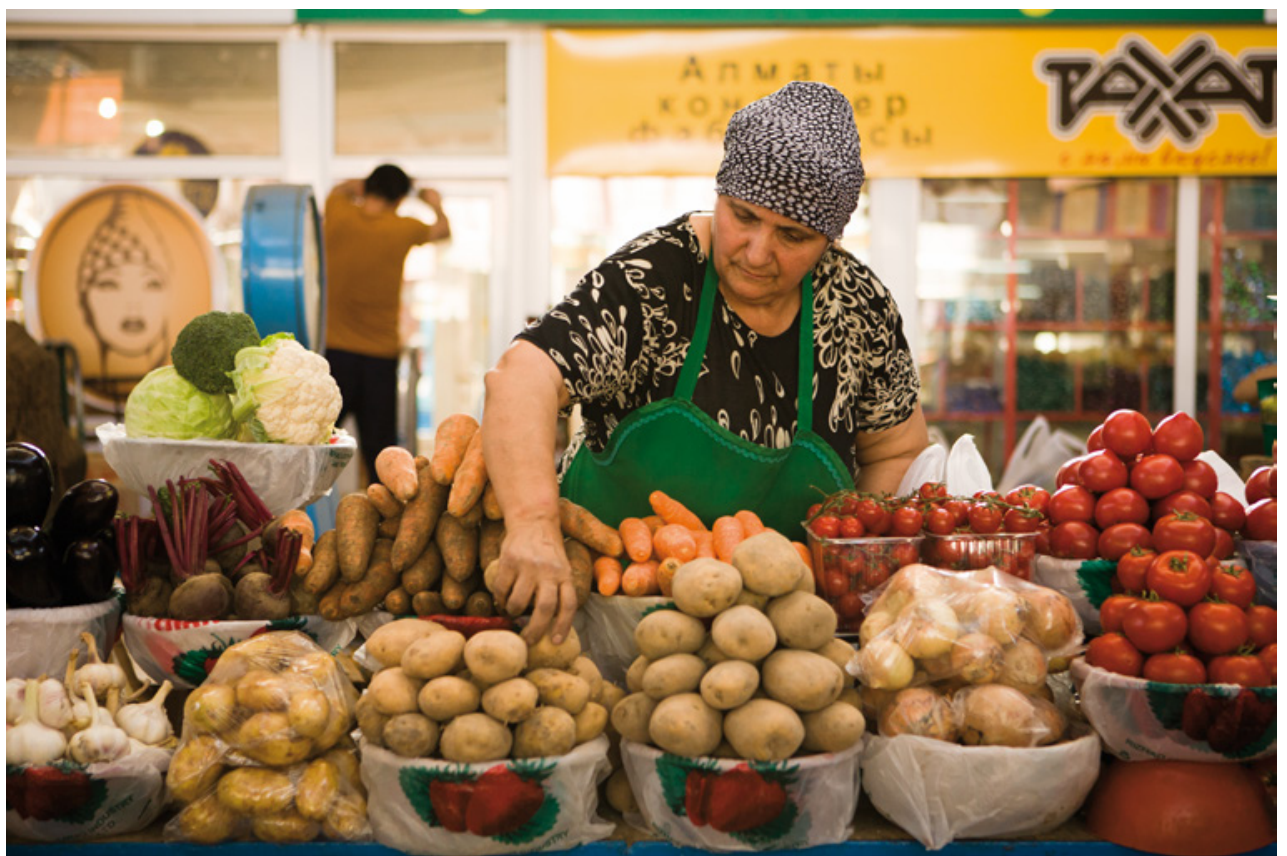

Рното 18 Almaty market 


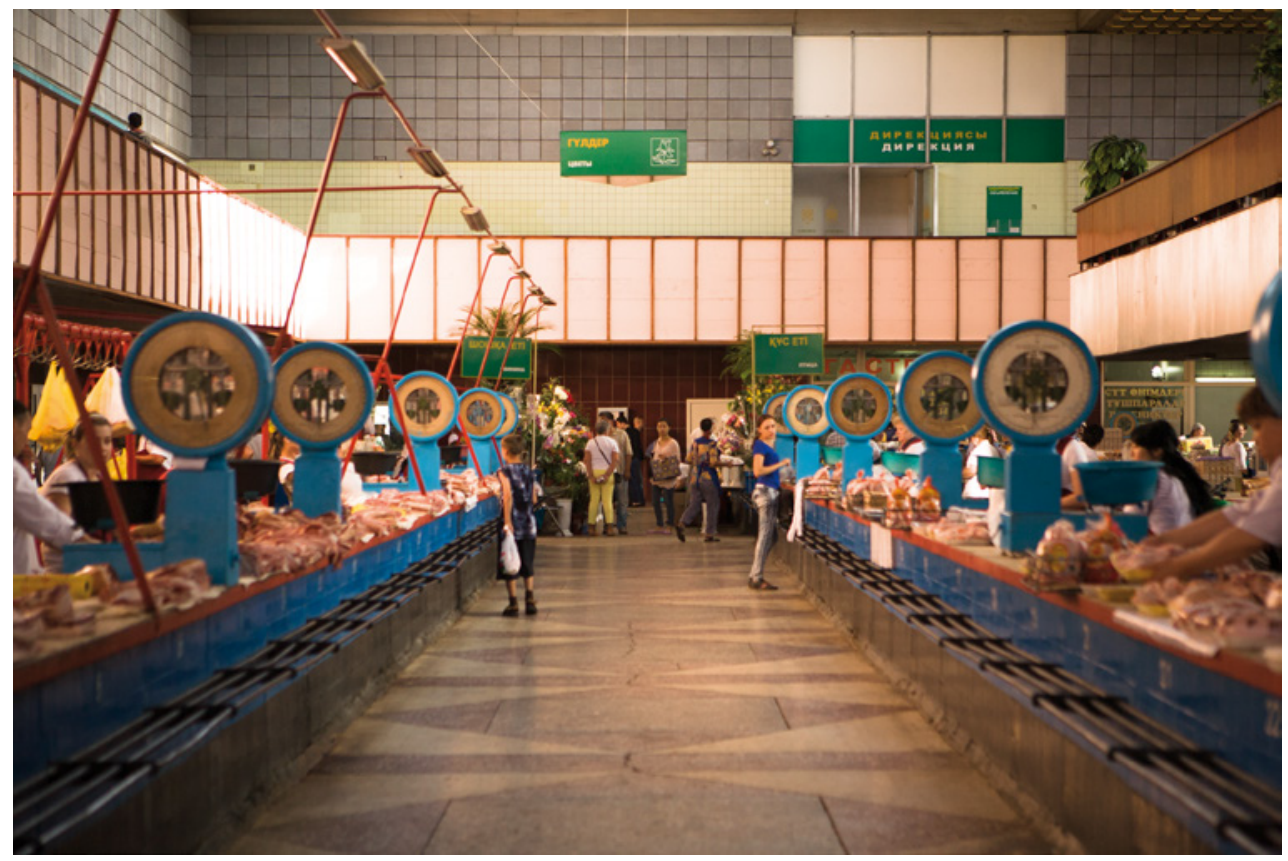

рното 19 Almaty market

other signature flavors have penetrated only in the most Chinese-influenced areas. In Kazakhstan, on the other hand, kimchi, produced by long-term Korean migrants with origins going back to Czarist times, was seen to be sold in the Almaty Public Market by Buell and de Pablo. It has also been introduced to Uzbekistan, in this case by a later wave of Korean migrants transplanted under Stalin.

Although not generally realized, another food tradition coming from the heartland is distilled milk liquor, such as Mongolian milk vodka (arkhi). The origins of distilling remain obscure-very possibly it was independently invented in China and the Near East. The steppes made innovations in distilling technology that survive in Mongolia and elsewhere, and in Korean soju. The Mongol Empire, spreading light-weight, portable stills east (to Korea for example), and west, to Russia, and even-indirectly - to Iceland, helped create a nearly universal culture of araq or arkhi. This is a borrowed Arabic word that is now employed almost universally in Eurasia, including its islands, beyond the reaches of most other vocabulary from Europe and China. ${ }^{65}$

65 Buell and de Pablo, "Distilling of the Volga Kalmucks and Mongols: Two Accounts from the 18th Century by Peter Pallas with some Modern Comparisons," Crossroads 13:3 (2016), 116-123. 
The end result of these adjustments, exchanges, and migrations was an ecological system that was remarkably uniform from the Caspian Sea to Lop Nor in Xinjiang. Basic to it was the relationship between settled oasis or mountain farmers and the local, transhumant, or truly nomadic stockraisers. Full nomadism, complete with its carefully planned and managed trade with settled folk, seems to have developed in the Bronze Age, around 1000-1500 BCE. It continued to develop, climaxing in the vast empires of the medieval period, established by nomad leaders but incorporating oases and depending on them for resources and manpower.

From that time on, the foodways of the great civilizations at the ends of the Silk Road penetrated more and more into Central Asian life. Iran was the clear winner: from medieval times onward, its foodways became more and more dominant. This was partly for ecological reasons: Iran's crops and agricultural technology and traditions did well under Central Asian conditions. The other great factor was religion: Persian foodways spread with Islam, and came to dominate in all the Islamic areas. Foodways from China influenced almost exclusively the areas under Chinese control during its greatest imperial expansions. Russian, East European, and Indian foodways penetrated only the areas directly adjacent to the cultural strongholds. One evidence of Persian influence is the widespread celebration of the pre-Islamic Persian festival Nauruz, the first day of spring, regarded as the first day of the solar year, and a time for feasting and picnicking. 